НАУЧНЫЙ ОБЗОР

\title{
RADIOLOGY IN DENTAL IMPLANTATION
}

\section{Serova N.S., Sokkar A., Pavlova O.Yu., Medhat A.}

he detailed review on dental implantation is presented including preoperative planning, intraoperative control and postoperative follow-up. Since successful outcome depends on the precise preparation for the surgical intervention, the range of radiological methods is described in the review as well as new methods and techniques of dental implantation. Advantages and limitations of different methods are presented with the summary of possible complications and their radiological appearance.

Keywords: dental implantation, X-ray, orthopantomography, MSCT, CBCT, 3D scanning, radiology, dentistry, prosthetics, complications.

Corresponding author: Pavlova O.Yu., e-mail: dr.olgapavlova@gmail.com

For citation: Serova N.S., Sokkar A., Pavlova O.Yu., Medhat A. Radiology in dental implantation. REJR 2021; 11(1):43-62. DOI: 10.21569/2222-7415-2021-11-1-43-62.

Received: 17.01.21 Accepted: 11.03.21

\section{АУЧЕВАЯ АИАГНОСТИКА В АЕНТААЬНОЙ ИМПААНТАЦИИ}

\author{
Серова Н.С., Соккар А., Пав^ова О.Ю., Медхат А.
}

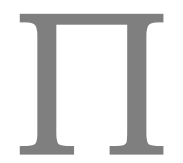

редставлен обзор митературы по теме дентальной имплантации, включая предоперационное планирование, интраоперационную навигацию и послеоперационный контроль. Так как успешный исход хирургического мечения напрямую зависит от точной подготовки к операции, в обзоре описан широкий спектр методов мучевой диагностики, а также новые методики и технические аспекты при дентальной имплантации. Представлены преимущества и ограничения различных методов мучевой диагностики, а также рентгенологические проявления возможных осложнений при дентальной имплантации.

Ключевые слова: дентальная имплантация, рентгенография, ортопантомогра-

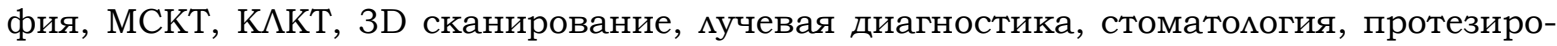
вание, осможнения.

Контактный автор: Павцова О.Ю., е-mail: dr.olgapavlova@gmail.com

Для иитирования: Серова Н.С., Соккар А., Павлова О.Ю., Медхат А. Иучевая диагностика в дентальной имплантации. REJR 2021; 11(1):43-62. DOI: 10.21569/22227415-2021-11-1-43-62.
Статья получена:
17.01.21
Статья принята:
11.03.21

I.M. Sechenov First Moscow State Medical University (Sechenov University). Moscow, Russia.
ФГАОУ ВО Первый МГМУ им. И.М.

Сеченова Минздрава России (Сеченовский Университет). Москва, Россия. 


\section{RUSSIAN ELECTRONIC JOURNAL OF RADIOLOGY}

I

ntroduction.

Implant placement or dental implantation is a very challenging procedure which requires different types of imaging to reach a successful procedure as it helps develop an appropriate and precise treatment plan for implantation [1-5]. Successful implant placement requires extensive planning. Evaluation of medical and intra-oral conditions to determine eligibility, combined with a thorough periodontal and dental assessment and radiographic evaluation will provide valuable information in planning and completing effective implant cases. Anatomic considerations of the area for implant placement should guide the appropriate radiological modalities as well as dimensional accuracy [1-5].

Radiology in dental implantation is done through the following phases:

- Pre-operative phase,

- Intraoperative phase,

- Post-operative phase.

Each step of these stages has different approach to minimizing the failure rate of operation and complications that can happen after the surgery [1-5].

The dental implants are replacement of tooth roots to restore the missing tooth (Fig.1). It provides a strong foundation for fixed prosthesis (permanent) or removable prosthesis replacement teeth that made to match the natural teeth $[2,3$, 4]. They are metal biocompatible anchors surgically positioned in the jaw bone underneath the gum tissue to support an artificial crown where natural dentition is missing [4]. It provides effective, predicable, and reliable means for tooth replacements. Additionally, dental implants provide partially edentulous and completely edentulous patients the aesthetics and function they had with natural

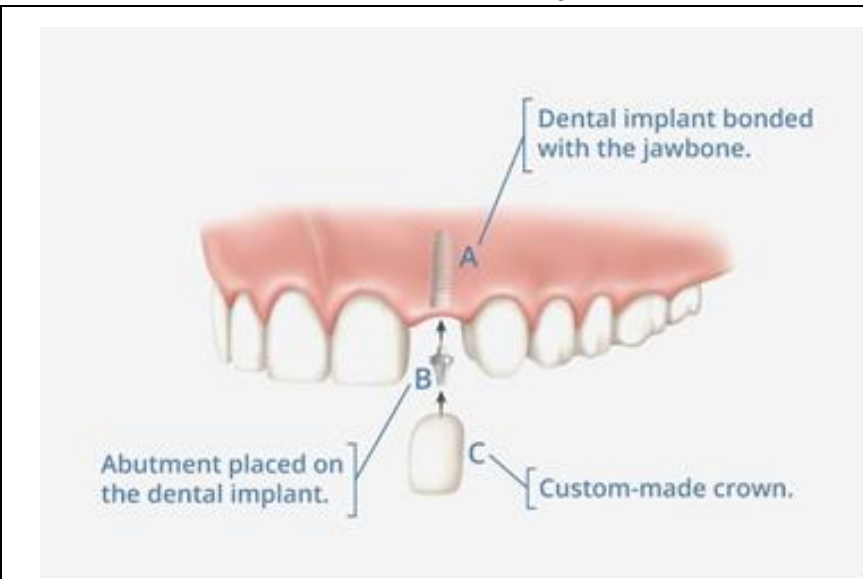

Fig. 1 (Рис. 1) dentition [1-5].

The dental implants are inserted into the bone, where bone integration process begins "osseointegration", which means fusion of the implant surface with the bone around it [1-5].

Back in time it was firstly admitted by Leonad Linkow in 1950, he is known as "Dental Impantology Godfather", he was the first one who inserted titanium into bone in voluntary patient [4].

There are several conditions for dental implantation [1-5]:

- missing one tooth or more,

- when adequate bone present to secure the implants or bone graft could be done,

- when oral tissue is healthy,

- if patient is unwilling or unable to wear dentures, thetics

- improvement of patient's speech and es-

- absence of systemic local disease that will affect bone healing .

Advantages of dental implantology are [1-5]:

- long lasting solution and cost effects,

- significant benefits in impairing quality of patient's life,

- jawbone support,

- durable,

- provide better oral hygiene,

- easy function and mastication,

- improved speech since edentations and mobile dentures can restrict pronunciation.

Types of dental implants.

1. Endosteal implants.

Endosteal dental implants are the most common type of dental implant, it is placed into one's jawbone by the path of the tooth root. These dental implants have different shape of screws,

\section{Fig. 1. Scheme.}

Dental implantation [2].

Рис. 1. Схема.

Дентальная импмантация [2].

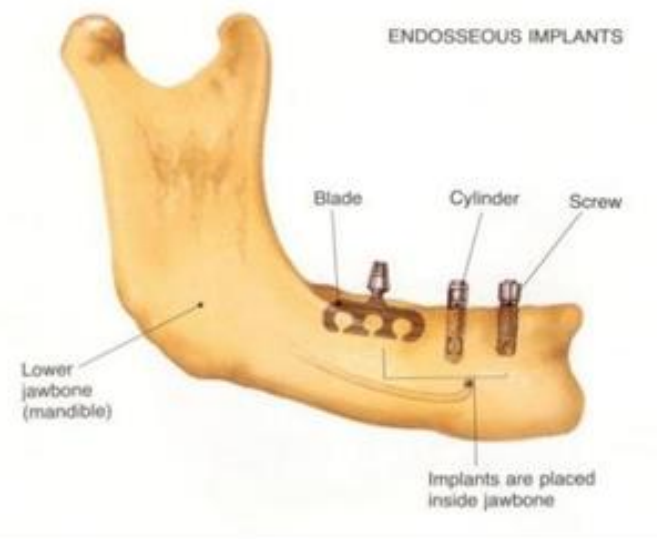

Fig. 2 (Рис. 2)

Fig. 2. Scheme.

Endosteal implants [4].

Рис. 2. Схема.

Эндостальный имплантат [4]. 
cylinders, or plates. "Root-form implants" are by far the most used implants in dentistry recently (Fig. 2). Osseo integrated root-form implants are made up of a fixture and an abutment. The fixture is the part of the implant that embedded surgically in the bone of the jaw. It is made of a material that promotes osteo-integration (titanium). They come in various sizes, ranging from $(3,25$ to 3,75 $\mathrm{mm}$ ) in diameter and (7 to $10 \mathrm{~mm}$ ) in length. The size of the implant and length depends on the amount of available bone. Dentists prefer the largest possible implant as it increases the surface area and provides stronger anchorage and better bone integration. It is preferred to have $1-1,5 \mathrm{~mm}$ of bone on either side of the implant fixture and 1$2 \mathrm{~mm}$ of bone between the implant surface and the adjacent vital structures like mandibular canal, maxillary sinus, nasal fossa. The abutment which increases the height of the fixture level above the gingival surface is attached to the fixture with an abutment screw. The top of the abutment screw has a small hole which allows the dental prosthesis to be attached by a screw that runs through the prosthesis and into the abutment screw [2-5].

\section{Subperiosteal implants.}

It is a less common form of dental implants; they are placed under the gumline but above the jawbone instead of inserting it into the jawbone like endosteal implants. Blade implants are rectangular, like a razor blade. From the long side of the rectangle, one or more posts extend into the oral cavity to allow fixation of the prosthesis (Fig. 3). Subperiosteal implants are used when the patient has insufficient jawbone density and placement of one's dental implants directly into the jawbone is not recommended [1-5].

3. Trans-osseous implants.

Trans-osseous implants still used for highly resorbed mandibles, they are placed in the anterior region between the 2 mental foramina. The trans-osseous dental implant is a very stable implant that acts like 4 standard root form implants. It is placed from the bottom of the jaw and protrudes through the upper part (Fig. 4). There is a bar that can be secured to it and a denture supported by the structure. This implantation is not performed by many dentists as it is very difficult and need special skills as well as it needs to be done in the hospital in most cases [1-5].

The size of dental implants varies with mini, narrow or shorter dental implants available for those with

insufficient gum and bone tissue which cannot withstand traditional dental implant sizes [1-5].

\section{Zygomatic implants.}

Zygomatic implants have been used for rehabilitation of the edentulous atrophic maxilla as an alternative to bone grafting for almost two decades resulting in satisfactory clinical outcomes. However, the patients with edentulous atrophic maxilla treated using this technique may present serious complications that could put the prosthetic restoration at risk [5, 6, 9].

Excessive bone resorption combined with poor bone quality and increased maxillary sinus pneumatization often making it impossible to place conventional dental implants in the posterior maxilla. Various bone augmentation techniques, such as sinus floor elevation and onlay bone grafting, have been described in order to in

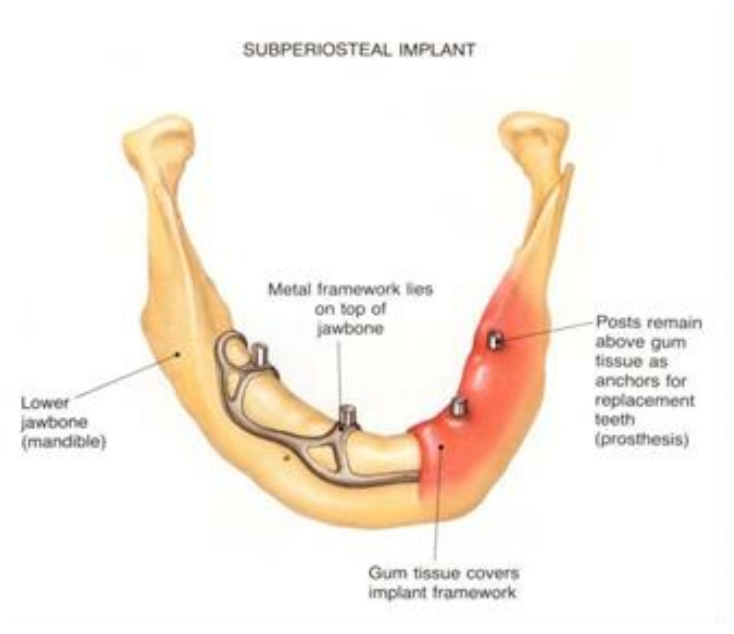

Fig. 3 (Рис. 3)

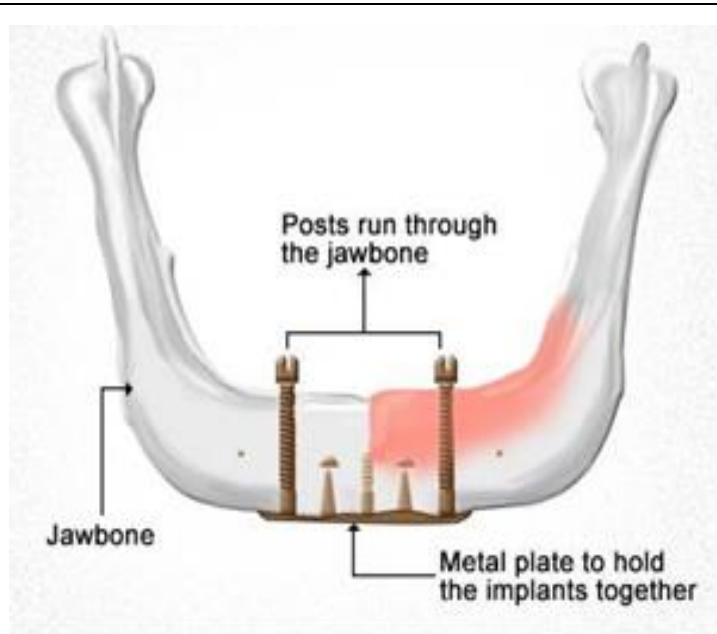

Fig. 4 (Рис. 4)

\section{Fig. 3. Scheme.}

Subperiosteal implants [4].

Рис. 3. Схема.

Субпериостальный имплантат [4].
Fig. 4. Scheme.

Trans-osseous implants [4].

Рис. 4. Схема.

Чрескостный имплантат [4]. 
crease the volume of load-bearing bone. Nevertheless, efforts have been made to pursue alternatives to grafting procedures and one of these, especially in the atrophic maxilla, is the use of zygomatic implants. This implant which was initially introduced for the prosthetic rehabilitation of patients with extensive defects of the maxilla caused by tumor resections, trauma or congenital defects was also used in patients with edentulous atrophic maxilla, enabling rehabilitation with sufficient function and improved esthetics. However, the placement of zygomatic implant is not deprived of risks, since it may involve delicate anatomical structures such as the orbit, and therefore surgical experience is required [5, 6, 9]. Additionally, many complications have been reported in the literature, with sinusitis being the most common (Fig. 5).

Imaging plays a very important part in dental implant procedures. The imaging modalities vary from standard projections that is available in

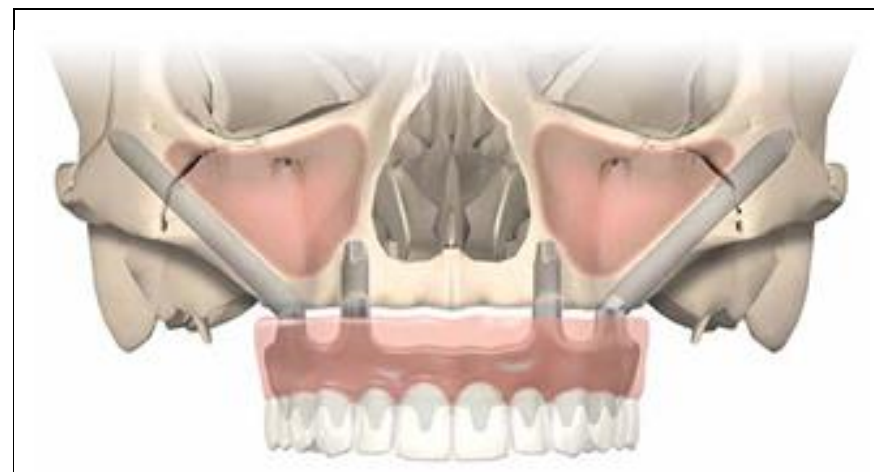

Fig. 5 (Рис. 5)

\section{Fig. 5. Scheme.}

Zygomatic implants [9].

\section{Рис. 5. Схема.}

Скуловой имплантат (зигома) [9].

the dental office to more complex radiographic techniques typically available only in radiology centers. Implant imaging provides reliable and accurate diagnostic information of the patient's anatomy at the proposed site of implant [5-8, 10]. $\mathrm{X}$-ray examination include intra-oral (periapical, occlusal) and extra-oral (panoramic, lateral cephalometric) radiographs. More complex imaging techniques include computed tomography (CT), and cone-beam computed tomography (CBCT).

The goals of imaging are [5-8, 10]:

- measuring bone height and width (bone dimensions),

- to assess bone quality and structure,

- to determine alveolar bone long axis,

- to identify internal anatomy and localize it,

- to detect jaw boundaries,
- to detect if any underlying pathology present.

\section{Preoperative assessment.}

A comprehensive evaluation of the oral cavity begins with a detailed medical and dental history, and a dental hard and soft tissue clinical examination. This is followed by panoramic radiography and cross-sectional imaging using multislice computed tomography or cone-beam computed tomography $[1,4,5,6,11]$.

Imaging in this phase determines the quantity, quality, and angulation of bone, relationship of critical structures to prospective implant sites; and the presence or absence of disease at the proposed surgical sites [5, 8, 14].

Important landmarks are:

- In the maxilla: nasal floor, naso-palatine canal, anterior superior alveolar canal, maxillary sinus and related structures, posterior superior alveolar canal, maxillary tuberosity, pterygoid plates,

- In the mandible: lingual foramen, incisive canal, genial tubercles, inferior alveolar nerve canal, mental foramina, retromolar foramen, sublingual fossa (lingual undercut), mylohyoid undercut, lingula of ascending ramus,

- In the zygomatic region: orbital floor, infraorbital foramen, zygomatic bone [5, 6, 12] (Fig. 6).

The selection for radiographic imaging depends on the amount of residual alveolar ridge atrophy: this includes the bone quality, bone quantity, remaining bone height, bone width, and available bone volume. The residual alveolar ridge topography needs to be understood and addressed rather carefully, as the positioning of an implant is crucial for prosthetic treatment planning [16, 17]. The identification of vital anatomic landmarks and their relation or vicinity to the future implant site/s is a crucial factor. Potential implant sites need to be safely identified.

The main methods that are used in preoperative planning of DI [5-8, 10, 11, 14-16]:

- Panoramic radiography,

- MSCT,

- CBCT.

1. Panoramic radiography.

These are narrow beam rotational tomographs, which use two or more centers of rotation with a predefined focal trough, to produce a radiographic image of both the upper and lower jaws. Optimal patient setting is crucial in this procedure because jaw positioning errors in the sagittal plane can occur easily, particularly in the edentulous patient. It provides an approximation of bone height, vital structures, and any pathological conditions if present [5, 6, 14-17].

The advantages of panoramic radiography are:

- providing information on opposing landmarks, vertical height of the bone, 


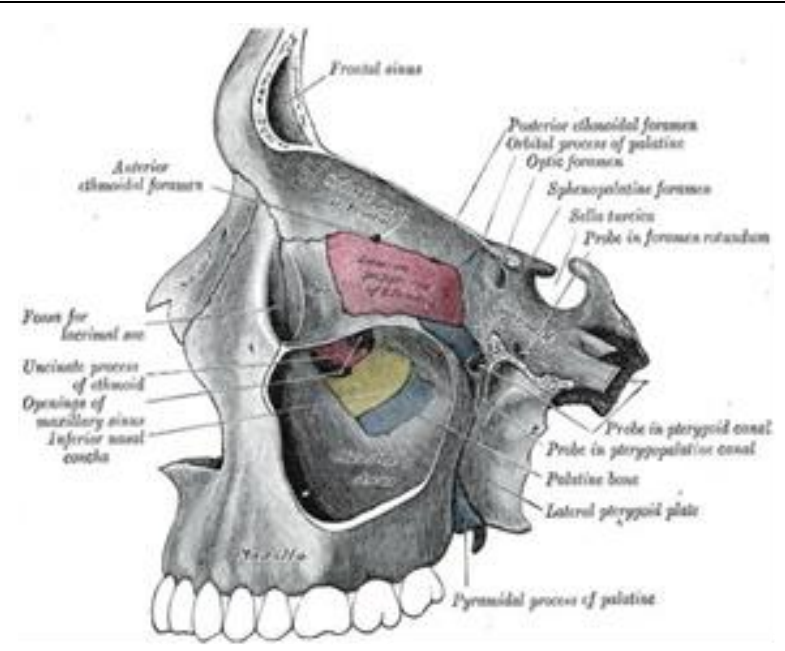

Fig. 6 a (Pис. 6 a)

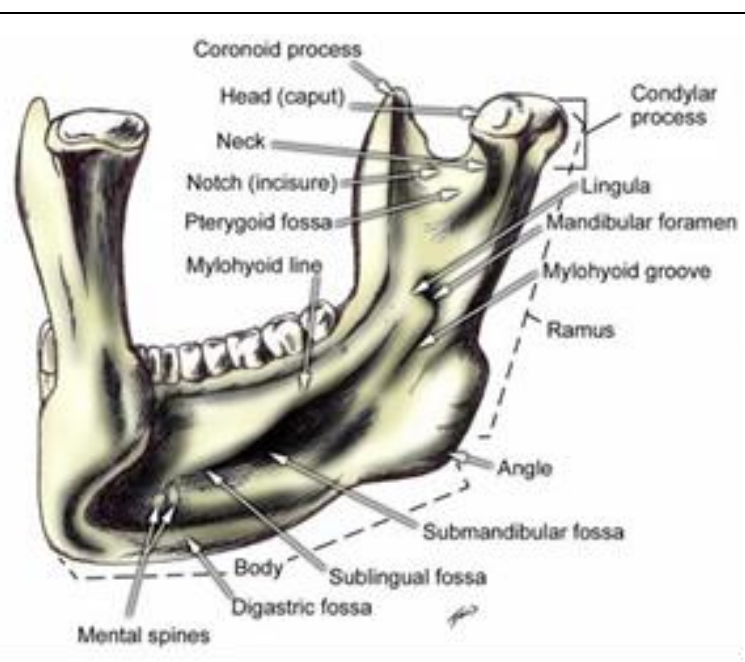

Fig. 6 b (Рис. 6 б)

Fig. 6. Scheme.

$\mathrm{a}$ - anatomy of maxillary region, b - anatomy of lower jaw [12].

Рис. 6. Схема.

a - анатомия верхнечелюстной области, б - анатомия нижней челюсти [12].

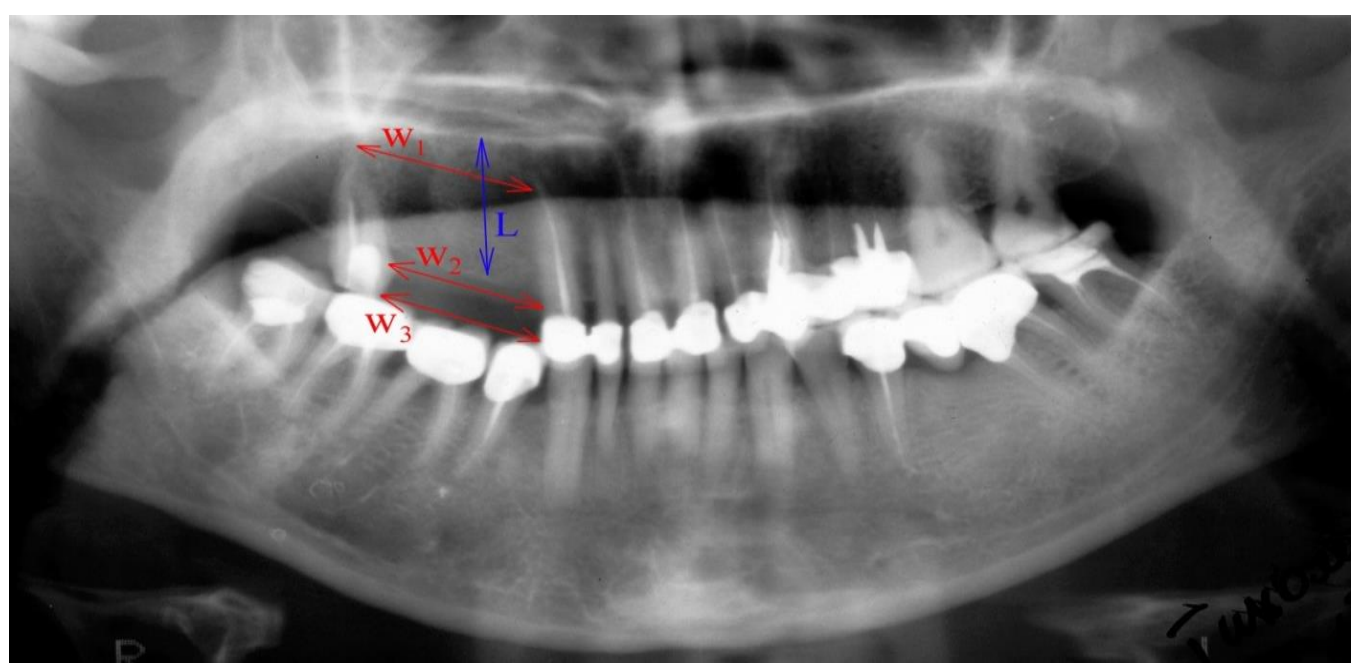

Fig. 7 (Рис. 7)

\section{Fig. 7. Panoramic radiography.}

W - mediodistal length of the defect: 1 - distance between the roots of adjacent teeth, 2 - distance at the level of the apex of the alveolar ridge; 3 - distance between the crowns of adjacent teeth; L - height of the alveolar part [5]. Рис. 7. Ортопантомограмма.

W - медиодистальная длина дефекта: 1 - расстояние между корнями соседних зубов, 2 - расстояние на уровне вершины альвеолярного гребня, 3 - расстояние мехду коронками ближайших зубов; L - высота альвеолярной части [5].

- assessing crestal alveolar bone and cortical boundaries,

- evaluating gross anatomy of the jaws and related pathologic conditions,

- relatively short exposure time, and comfort and simplicity of examination [5, 6, 14-17].

Panoramic radiography in implant procedure could be used in pre-surgical phase as it is the most used diagnostic modality. The image receptor may be "a radiograph film, a digital storage phosphor plate or a digital charge coupled device receptor". Complete imaging of both jaws could be obtained in one film [5, 14-17] (Fig. 7).

Limited-angle linear tomography (zonography) is used as a means for patient positioning for making a cross-sectiona 1 image of the jaws to 


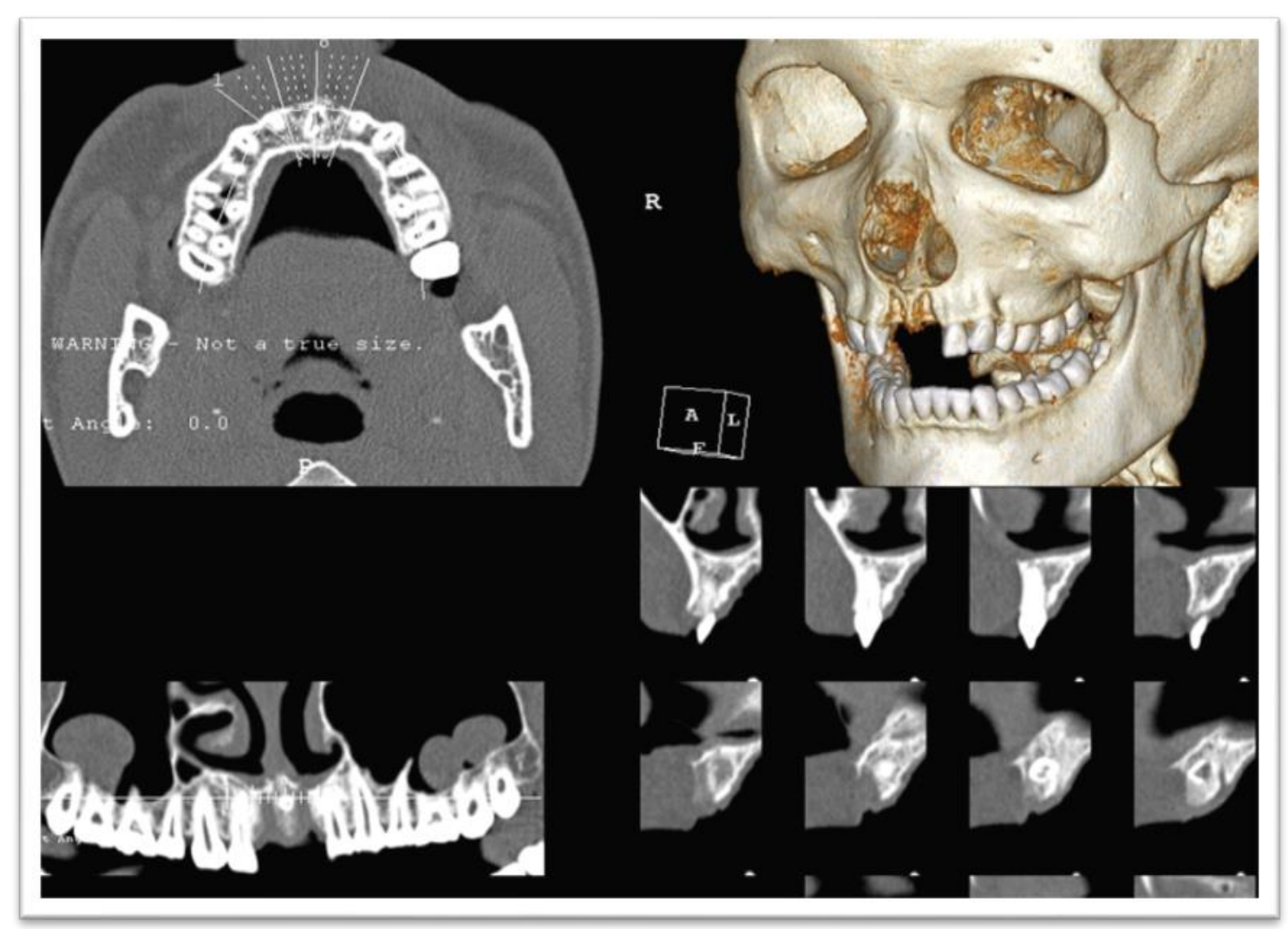

Fig. 8 (Рис. 8)

\section{Fig. 8. Multispiral computed tomography, multiplanar reconstructions.}

Secondary (post-traumatic) edentulous teeth 1.1 and 2.1. Planning of dental implantation in the area of missing teeth [5].

Рис. 8. Мультиспиральная компьютерная томография, мультипланарные реконструкции.

Вторичная (посттравматическая) адентия зубов 1.1 и 2.1. Планирование дентальной имплантации в области отсутствующих зубов [5].

modify the panoramic X-ray machine. The tomographic layer is approximately $5 \mathrm{~mm}$ thick, which helps to determine the distance between the critical structures and the implant site, as well as the bone quantity at the site of implant placement [5, 14-17].

A good panoramic radiograph will outline the bony anatomy clearly and is generally used for diagnosis of gross pathoses within the jaws as well as the relation of anatomic structures such as sinuses, canals, fossae and foraminae to the implant site. Although some panoramic machines have uniform magnification (19\%), in general, most machines have varied and unreliable magnifications $(25 \%$ to $30 \%)$ especially in the vertical dimension [5, 6, 15-17]. Magnification is more pronounced in posterior than in anterior areas. This may give a false sense that more bone exists between the crest of the alveolar process and the inferior alveolar canal, nasal fossae, or maxillary sinuses. Improper patient positioning may further contribute to image distortion. Even properly positioned and exposed panoramic radiographs can- not be used for direct bony measurements unless the magnification factor for the target area is predetermined.

A technique for evaluating the panoramic radiograph for mandibular posterior implants, as well as for a comparison with the clinical evaluation during surgery was developed by identifying the mental foramen and the posterior extent of the inferior alveolar canal $[5,16,17]$. However, studies have demonstrated that the mandibular foramen cannot be identified $<50 \%$ of the time on the radiograph film and, when visible, it may not be identified correctly.

The disadvantages of this modality are [5, 14-17]:

- distortion of the visualized structures,

- low level of reproducibility,

- times magnification of the structures,

- difficulty in assessing hard tissue morphology and density of the bone,

- little information about the buccolingual cross-sectional dimension,

- inadequate identification of critical struc 


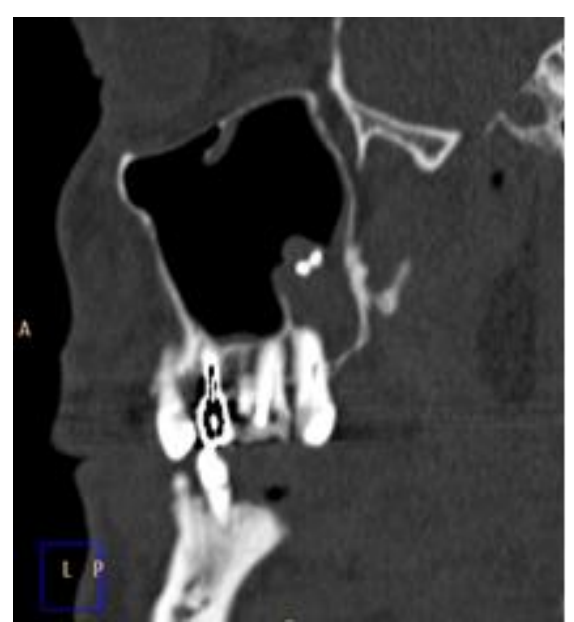

Fig. 9 a (Pис. 9 a)

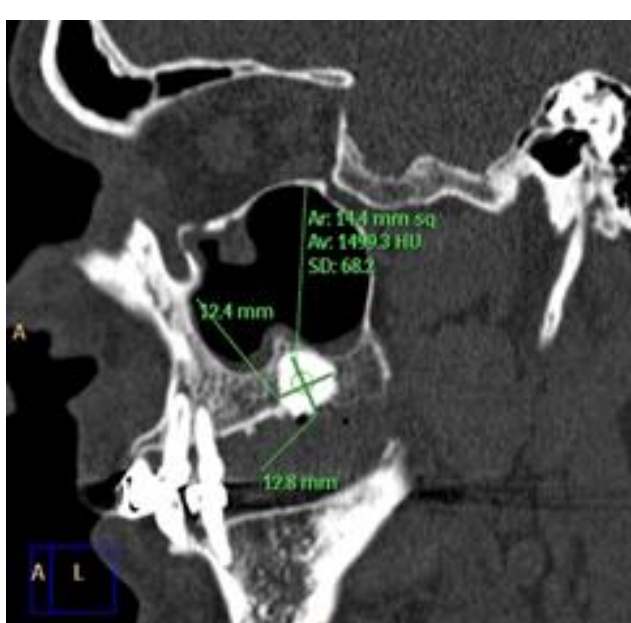

Fig. 9 b (Рис. 9 б)

\section{Fig. 9. MSCT, sagittal (a) and coronal (b) reconstruction.}

Incomplete secondary adentia of the upper jaw. In the area of missing teeth 2.6 and 2.7 , a focus of bone compact tissue of a rounded shape with size of $14 \times 10 \times 12 \mathrm{~mm}$ and density of $1500 \mathrm{HU}$, with homogeneous structure, occupying the entire thickness of the alveolar process and extending to the walls of the nasal cavity and maxillary sinus is determined. This formation corresponds to the intraosseous osteoma of the alveolar process of the upper jaw [5].

\section{Рис. 9. МСКТ, сагиттальная (а) и корональная (б) реконструкции.}

Неполная вторичная адентия верхней челюсти. В области отсутствующих зубов 2.6 и 2.7 определяется очаг уплотнения костной структуры округлой формы размерами 14х10х12 мм, плотностью 1500 НU, гомогенной структуры, занимающий всю толщину альвеолярного отростка и распространяющийся к стенкам полости носа и верхнечелюстного синуса. Данное образование соответствует внутрикостной остеоме альвеолярного отростка верхней челюсти [5].

tures,

- no data of spatial relationships between the structures,

- patient positioning errors, however with knowledge, most errors in patient positioning can be corrected,

- the patient must leave the surgical room and stand still for imaging purposes,

- the resolution of the image is less compared to periapical images,

- zonography fails to identify disease at the implant site or to access the differences in bone densities.

2. Multispiral computed tomography.

CT was invented by Godfrey Hounsfield and Allan Cormack in 1972. This modality gives rise to high-density resolution images and allows soft tissues to be visualized. The reformatted CT image generates axial, panoramic, and cross-sectional images that allow rapid correlation of the different views. CT scan provides tangential and crosssectional tomographic images of the implant site the density of structures produced in the image is absolute and quantitative, and can be used to differentiate tissues in the region and characterize bone quality $[5,6,14,16]$.

Disadvantages include limited availability of CT scanners, high cost of machines, image arti- facts caused by metal and the need for special training in image interpretation.

CT images are indicated if the patient is being evaluated for total jaw reconstruction or for multiple implants within the mandible or maxilla. They are also recommended if ridge augmentation is required, if the sinuses may be breached during the procedure or if there are variations in the anatomy, atrophic changes, or pathology. The thickness of the image layer must be adequate to achieve proper coverage; generally, a 0,5-1 $\mathrm{mm}$ layer is indicated (Fig. 8-9) [5, 6, 14-17].

3. Cone-beam computed tomography.

CBCT scanners are designed specifically for diagnosis and treatment planning in implant therapy. Multiple pictures of the region of interest are generated in a single scan. This enables the dentist to have precise diagnostic information and therefore perform minimally invasive surgery with reduced surgery time, postoperative pain and swelling, and faster recovery time $[4,5,6,11,13$, 14-17].

CBCT is valuable for the evaluation of the mandible, maxilla and facial bones. CBCT scans of the mandible can help clinicians determine the size of the lingual concavity in the symphyseal regions. Occasionally, the mandible may have an unexpected lingual concavity in the posterior re- 


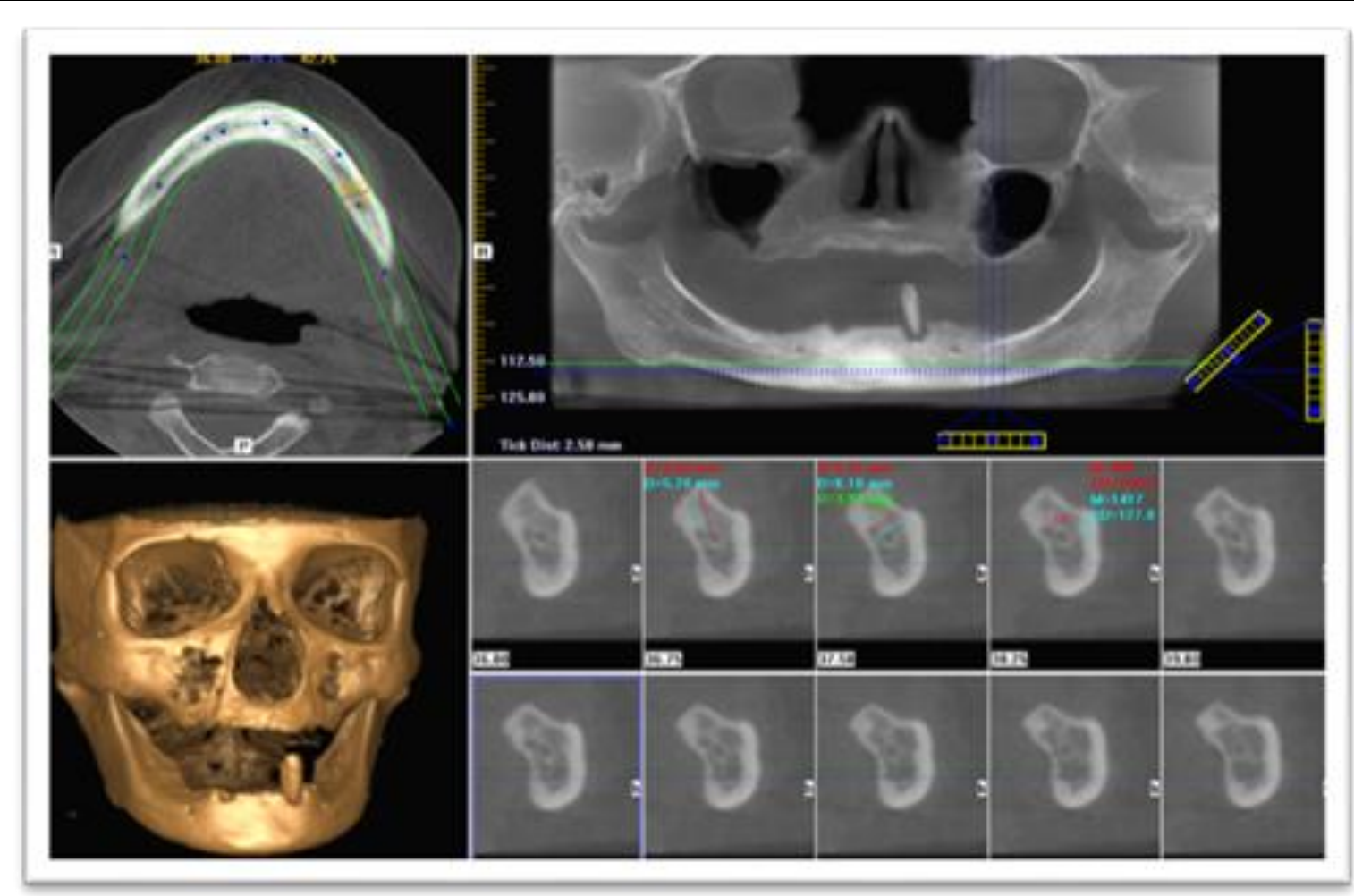

Fig. 10 (Рис. 10)

Fig. 10. $\quad \mathrm{CBCT}$, condition before DI.

Assessment of parameters of the jaw's alveolar parts, severe atrophy of both jaws [5].

Рис. 10. КАКТ, состояние переА АИ.

Оценка параметров альвеолярных отделов челюстей, выраженная атрофия обеих челюстей [5].

gion of the mandible. In the inferior alveolar canal (IAC), CBCT scans can show whether the canal is single or divided and how it is placed buccolingually (Fig. 10-11).

CBCT-aided implant surgery can be divided into the following: passive, semi-active, and active.

1. Passive CBCT-aided implant surgery refers to the use of CBCT information such as linear measurements, relative bone quality, 3D evaluation of ridge topography, and proximity to vital anatomical structures to help in the implant treatment planning process. Passive CBCT-aided implant surgery can be accomplished with or without third-party interactive treatment planning software [5, 6, 11, 13, 14-17].

2. Semi-active CBCT-aided implant surgery includes the use of CBCT data imported into third-party interactive treatment planning soft ware where virtual implants are simulated as a precursor to the fabrication of surgical guides that will be used at the time of implant placement. Depending on the software application's protocol to relate implant position to the underlying bone and restorative needs of the patient, a scanning template may need to be fabricated before the scan acquisition. The scanning template can be made with a radiopaque material (barium sulfate), con- tain gutta-percha markers, or other specific fiduciary markers that aid in the fabrication of the surgical guide. The scanning template is positioned intraorally, and the CBCT scan is acquired $[5,6,11,13,14-17]$.

3. Active CBCT-aided implant surgery refers to the use $\mathrm{CBCT}$ data and surgical navigation systems to perform fully computer-guided implant placement. One of the main concerns of postimplant evaluation with CBCT is the presence of beam hardening and partial volume artifacts around implants which in some cases prevent the visualization of the bone-implant interface. However, scattering artifacts caused by metal are significantly less with CBCT as compared with medical CT. Naitoh et al in 2010 evaluated the rate of bone to implant contact in a clinical study and reported that the bone configuration surrounding anterior dental implants with and without bone grafting can be adequately assessed using CBCT. With the help of Digital Imaging and Communications in Medicine (DICOM) data, computergenerated surgical guides (stereolithographic models) can be fabricated from the CBCT data. The guide helps the surgeon place implants in their optimal and exact position $[4,5,6,11,13$, 14-17]. 


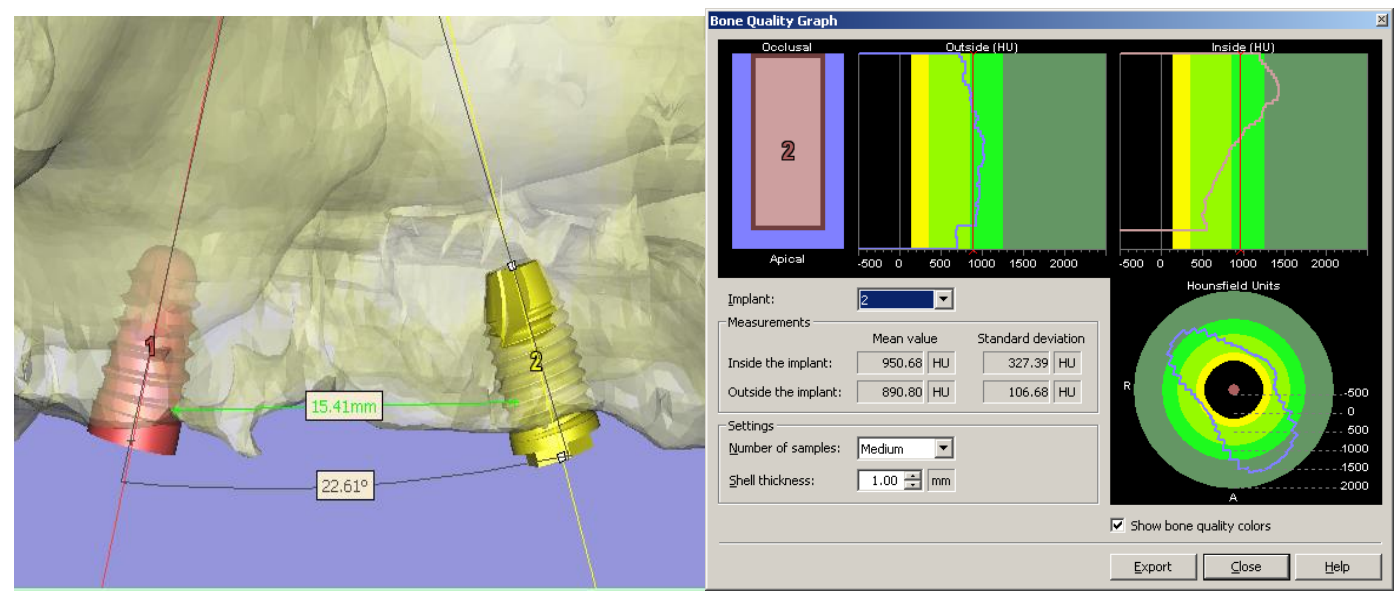

Fig. 11 (Рис. 11)

Fig. 11. Planning of dental implantation using an additional specialized program based on CT data.

Рис. 11. Планирование стоматологической имп^антации с помощью Аополнительной специализированной программы на основе Аанных КТ [5, 6].

Advantages of CBCT are that it generates a 3D dataset (digitally reconstructed image with 670 projections), has the potential for generating all 2D images (e.g. orthopantomogram, lateral cephalogram), and allows vertical scanning with the patient in a seated position CBCT generates highresolution images of anatomical structures, bone trabeculae, periodontal ligament (PDL), and root formation. The other advantages include rapid scanning procedure, lower radiation dose, reduced disturbance from metal artifacts, lower cost, easy accessibility, easy handling, and DICOM compatibility [4, 5, 6, 11, 13, 14-17] (Fig. 12-13).

CBCT has some disadvantages. It has a low contrast range, restricted field of view (FOV), reduced scanned volume caused by limited detector size gives little information about the inner soft tissue, and increased noise from scatter radiation and artifacts $[4,5,6,11,13,14-17]$.

According to U. Lekholm and G. Zarb (1985) classification, there are 4 types of quality of bone tissue. C. Misch in 1999 developed the 4 types of bone tissue quality (D1-D4) according to Hounsfield unites (Table 1) [4, 5, 14].

\section{Intraoperative implant imaging.}

During surgical implant placement, intraoperative imaging is limited to quick, in-office modalities, including digital-based periapical and panoramic radiography. These radiographs confirm appropriate pilot drill position and allow early errors to be identified so that appropriate modifications to the remaining osteotomy steps can be made. Occasionally, surgical accidents may require advanced radiologic imaging in the intraoperative phase, for example, when an implant is displaced into the maxillary sinus or placed through the inferior alveolar canal. In such situations, CBCT imaging will accurately locate the im- plant or assess the extent of nerve canal encroachment [5, 6, 17-19].

Along with studying the optimal position and orientation of the implant, intraoperative implant imaging helps evaluate the healing and integration of surgery sites. The correct position of the abutment and prosthesis fabrication are ensured in this phase $[5,6,17]$.

The goals of imaging are [5, 6, 17-19]:

- to assess the quality of implanting screws during the procedure,

- to clarify implant screw placing,

- determining the long axis of alveolar bone,

- identifying and localizing the internal position of the implant,

- to establish the boundaries of the jaw,

- to detect if any underlying pathology present (Fig. 14-17).

Post-prosthetic implant imaging.

This phase commences just start the after placement of the prosthesis and continues as long as the implant remains in the jaw [5, 6, 19-21].

Postoperative imaging and monitoring immediately following implant placement, a periapical image should be acquired to serve as a baseline image for future comparisons. If multiple implants have been placed, a panoramic image may be appropriate. During the prosthetic phase of treatment, periapical or bite-wing images may be made to ensure complete seating of the implant abutment and restoration. When such images are made, it is important to position the central beam as perpendicular to the longitudinal axis of the implant fixture as possible.

Small angular deviations may result in overlapping of the implant threads and allow small gaps between the fixture and prosthesis to become unnoticed [5, 6, 19-21]. Postoperative imaging for 

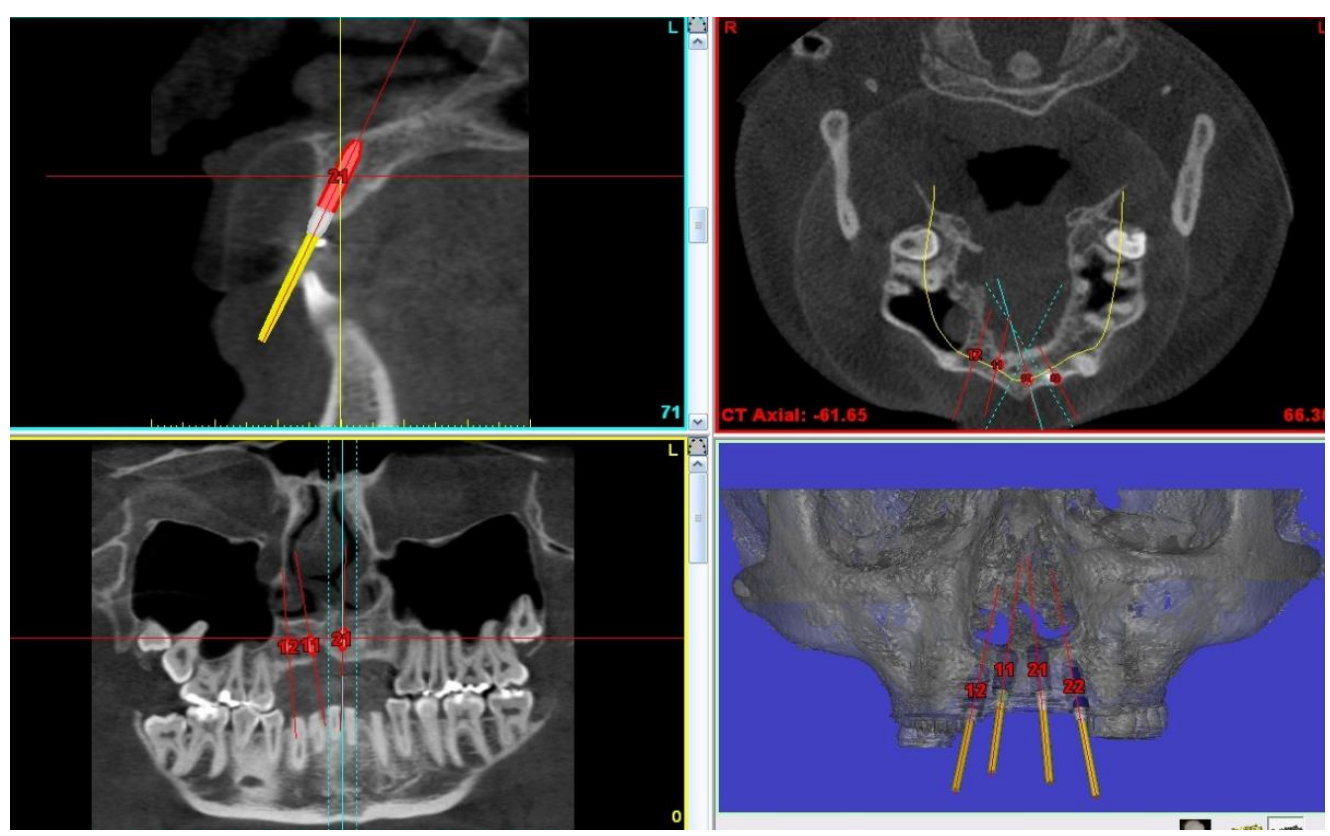

Fig. 12 (Рис. 12)

Fig. 12. $\mathrm{CBCT}$ with an additional specialized program Simplant made it possible to reliably assess the parameters of the alveolar ridge, as well as to select the implants that are optimal in shape and size and virtually position them $[5,6]$.

Рис. 12. КАКТ с Аополнительной специализированной программой Simplant Аали возможность Аостоверно оценить параметры альвеолярного отростка, а также выбрать оптимальные по форме и размерам имплантаты и виртуально их расположить $[5,6]$.

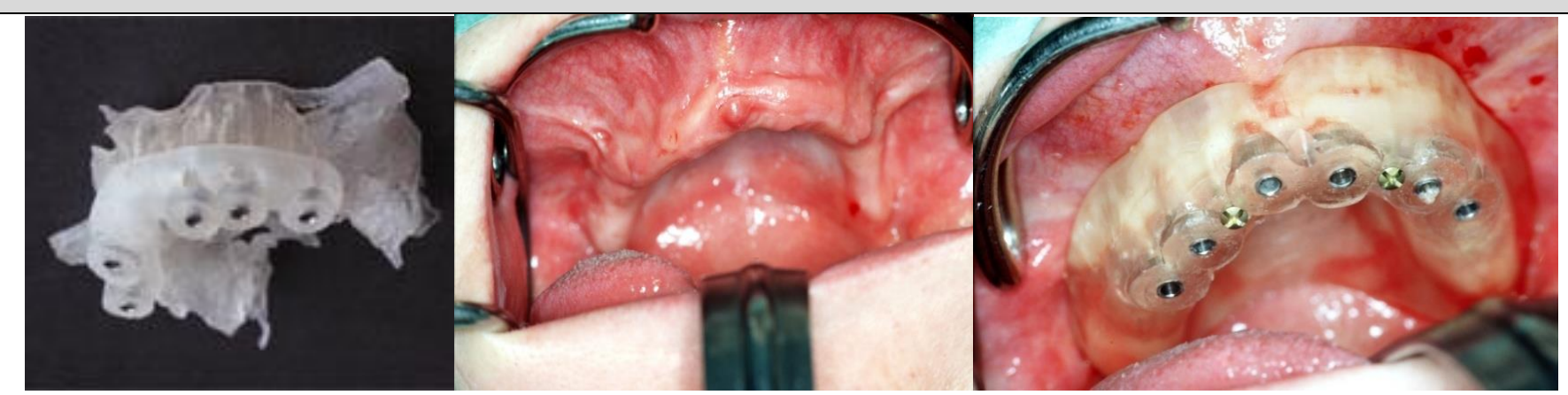

Fig. 13 (Рис. 13)

Fig. 13. Manufacturing of an individual surgical template, preparation of the implantation bed after fixation of the extra-bone surgical template with guides [6].

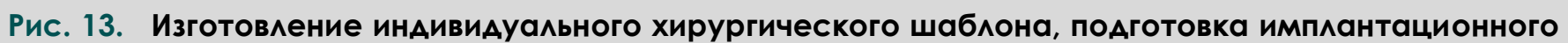
^ожа после фиксации накостного хирургического шаблона с направляющими [6]. 


\begin{tabular}{|c|c|c|}
\hline \multicolumn{2}{|c|}{ Table №1. Assessment of density and architectonics of the jaw's alveolar parts. } \\
\hline The type of bone tissue & $\begin{array}{c}\text { The type of bone tissue according to U. } \\
\text { Lekholm and G. Zarb (1985) }\end{array}$ & $\begin{array}{c}\text { Correspondence of bone tissue type } \\
\text { to Hounsfield unites according to C. } \\
\text { Misch (1999) }\end{array}$ \\
\hline D 1 & Homogeneous cortical bone tissue & More than 1250 HU \\
\hline D 2 & $\begin{array}{l}\text { Spongiform bone, surrounded by } \\
\text { compacted cortical bone tissue }\end{array}$ & $850-1250 \mathrm{HU}$ \\
\hline D 3 & $\begin{array}{l}\text { Spongiform bone, surrounded by thin } \\
\text { cortical bone tissue }\end{array}$ & $350-850 \mathrm{HU}$ \\
\hline D 4 & Homogeneous spongiform bone tissue & $150-350 \mathrm{HU}$ \\
\hline
\end{tabular}

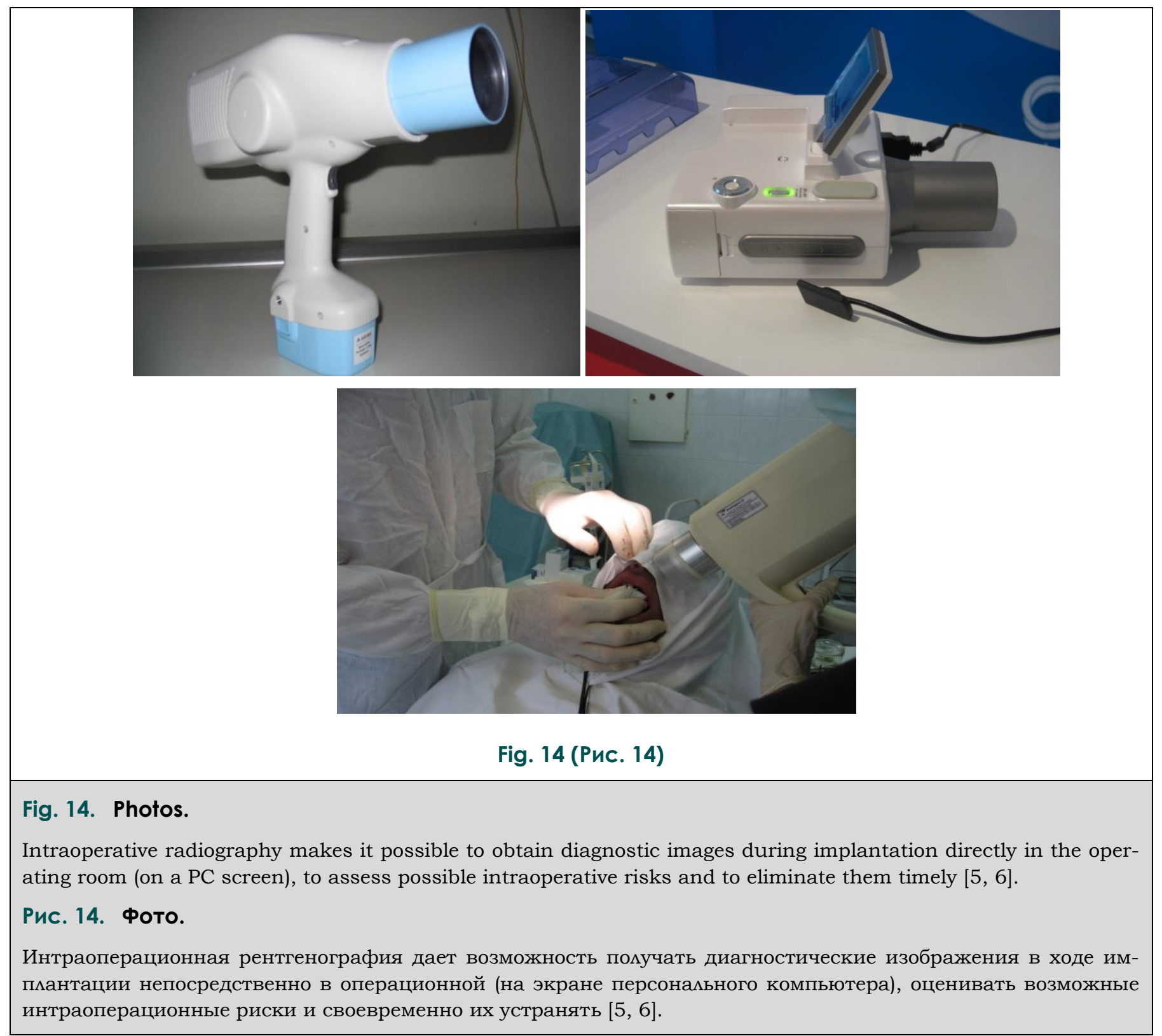




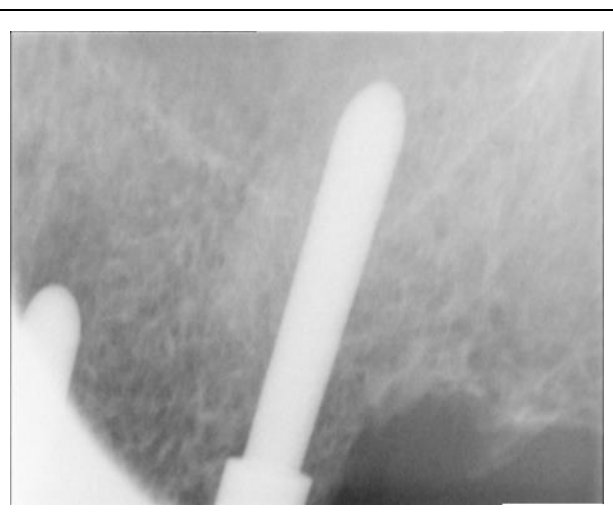

Fig. 15 a (Рис. 15 a)

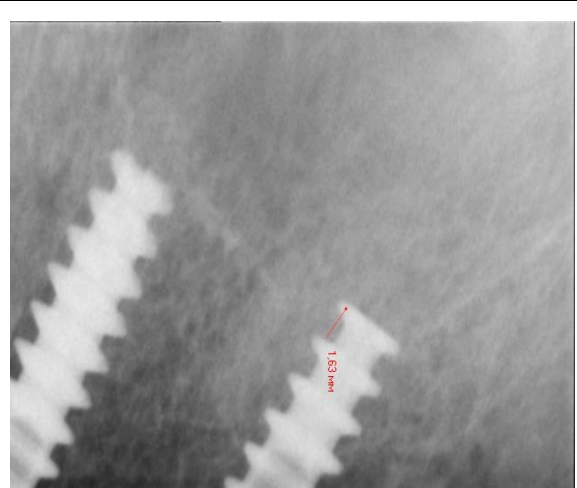

Fig. 15 b (Рис. 15 б)

Fig. 15. Digital microfocus radiographs, performed during the DI in areas 2.5 and 2.7 at the stage of formation of the implantation bed 2.7 (a) and after implantation (b).

Perforation of the maxillary sinus lower wall is determined at the stage of bed formation - the apical part of the depth gauge is located $3 \mathrm{~mm}$ above the maxillary sinus wall (a). During the operation, the implant 2.7 was placed with a smaller depth, its apical part is located $1 \mathrm{~mm}$ above the sinus wall in the submucosal layer (b) [5, 6].

Рис. 15. Цифровые микроффокусные рентгенограммы, выполненные в ходе операции имплантации в области 2.5 и 2.7 на этапе формирования имплантационного ложа 2.7 (a) и после установКи имплантатов (б).

Определяется перфорация нижней стенки верхнечелюстного синуса на этапе формирования можа - апикальная часть глубиномера расположена на 3 мм выше дня верхнечелюстного синуса (a). Во время операции имплантат 2.7 был установлен с меньшим заглублением, его апикальная часть располагается на 1 мм выше стенки синуса в подслизистом слое (б) $[5,6]$.

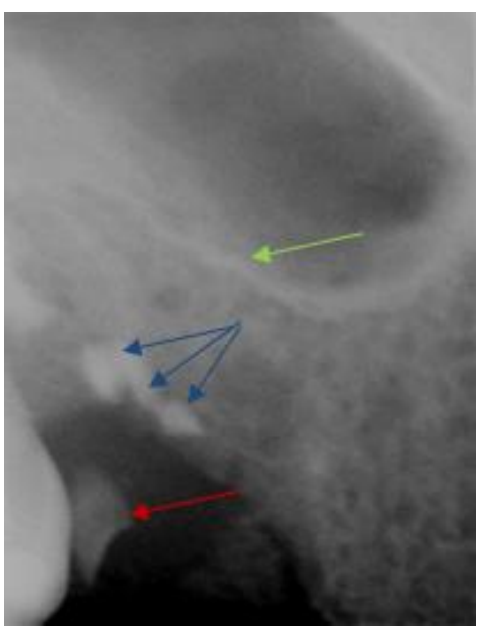

Fig. 16 a (Pис. 16 a)

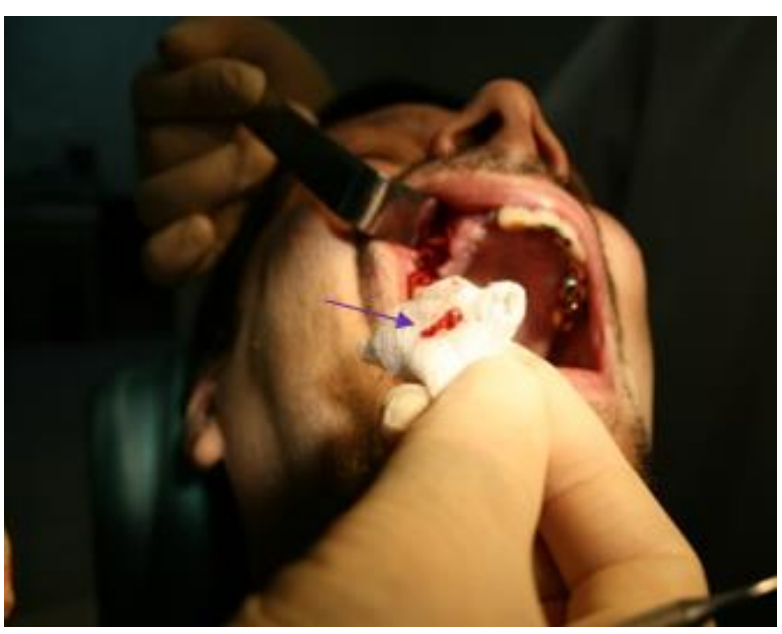

Fig. 16 b (Рис. 16 б)

Fig. 16. Intraoperative digital microfocus X-ray (a), performed before the formation of the implantation bed. A photograph taken during the operation at the stage of removing the filling material (purple arrow) (b) $[5,6]$.

3 foreign bodies corresponding to the filling material (blue arrows) and a bone fragment in the projection of soft tissues (red arrow) are identified, which located at a sufficient distance from the lower wall of the maxillary sinus (green arrow),

Рис. 16. Интраоперационная цифровая микрофокусная рентгенограмма, выполненная Ао формирования имплантационного ложа (а). Фотография, выполненная в хоАе операции на этапе УАаления пломбировочного материала (сиреневая стрелка) [5, 6] (б).

Определяются 3 инородных тела, соответствующие пломбировочному материалу (синие стрелки), и костный фрагмент в проекции мягких тканей (красная стрелка), находящиеся на достаточном расстоянии от нижней стенки верхнечелюстного синуса (зеленая стрелка); 


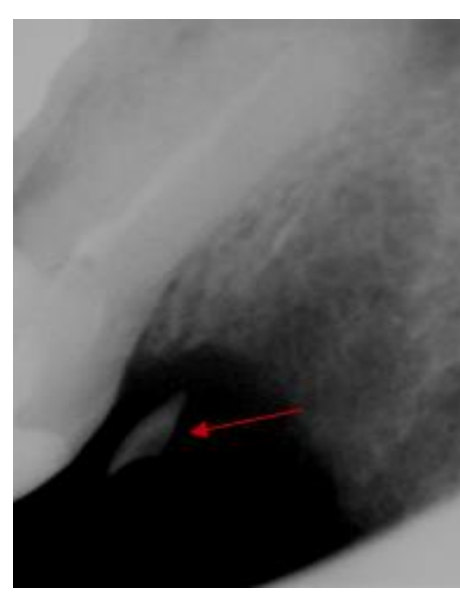

Fig. 17 a (Рис. 17 a)

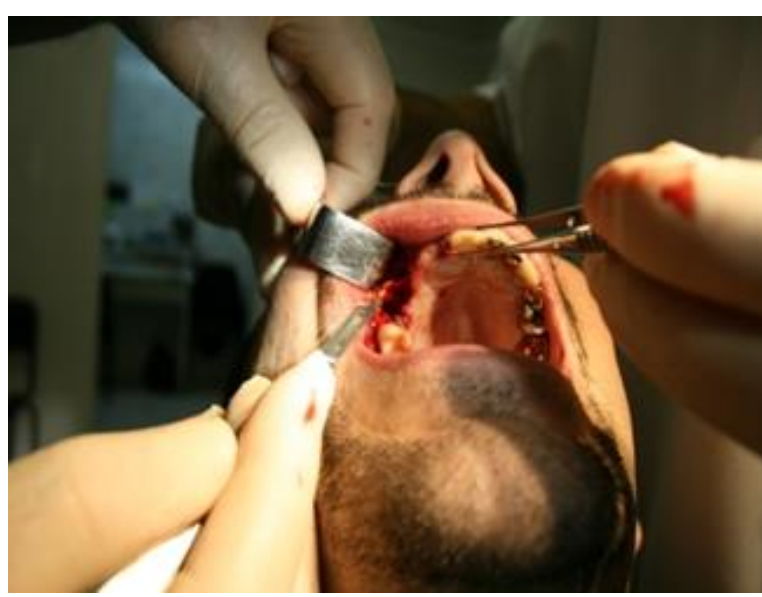

Fig. 17 b (Рис. 17 б)

Fig. 17. Intraoperative digital microfocus X-ray, performed before the formation of the implantation bed after complete removal of the filling materia (a). Photo, taken during the operation at the stage of bone fragment removing located in the soft tissues in the area of the planned implantation $[5,6](b)$.

$\mathrm{X}$-ray control made it possible to assess the quality of its removal and subsequent extraction of the bone fragment (arrow).

Рис. 17. Интраоперационная цифровая микрофокусная рентгенограмма, выполненная Ао формирования имплантационного ^ожа после полного уАаления пломбировочного материала (a). Фотография, выполненная в хоАе операции на этапе уАаления костного фрагмента, распологающегося в мягких тканях в зоне планируемой имплантации $[5,6] .(6)$

Рентгенологический контроль позволиц оценить качество его удаления и последующего извлечения костного фрагмента (указано стрелкой).

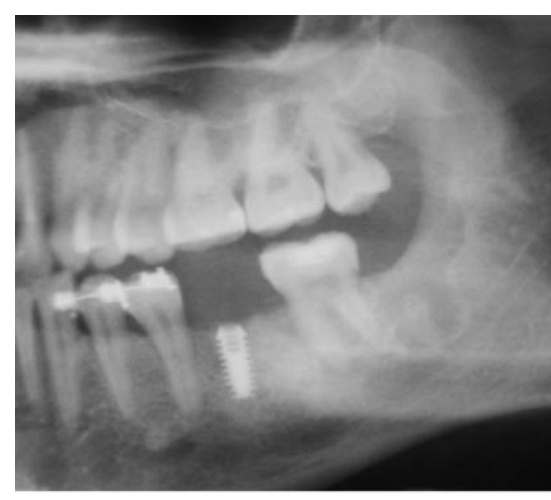

Fig. 18 a (Рис. 18 a)

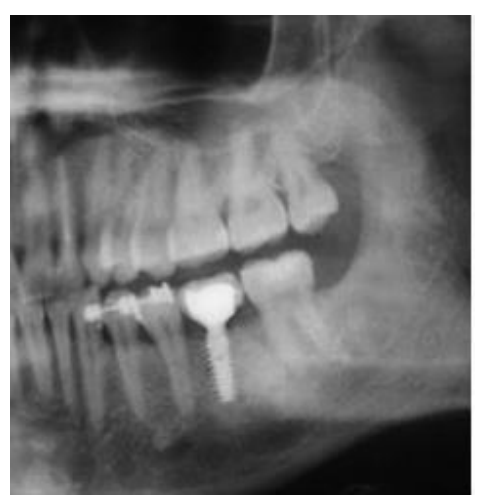

Fig. 18 b (Рис. 18 б)

Fig. 18. Orthopantomograms (fragments).

a - before the installation of the orthopedic structure ( 3 months after dental implantation in the area of tooth 3.6 , radiological signs of satisfactory osseointegration are determined, favorable conditions for further treatment and the formation of the load on the implant),

b - 1 year after orthopedic treatment (there is a moderate resorption of bone tissue in the cervical region, not exceeding $1,5 \mathrm{~mm}$, there are no bone-destructive changes in the peri-implanar region) $[5,6]$.

Рис. 18. Ортопантомограммы (фррагменты).

a - перед установкой ортопедической конструкции (3 месяца после дентальной исплантации в области зуба 3.6; определяются рентгенологические признаки удовлетворительной остеоинтеграции, благоприятные условия для дальнейшего мечения и формирования нагрузки на имплантат),

b - через 1 год после ортопедического мечения (отмечается умеренная резорбция костной ткани в пришеечной области, не превышающая 1,5 мм, костно-деструктивных изменений в периимпланарной области не выявцяется) $[5,6]$. 


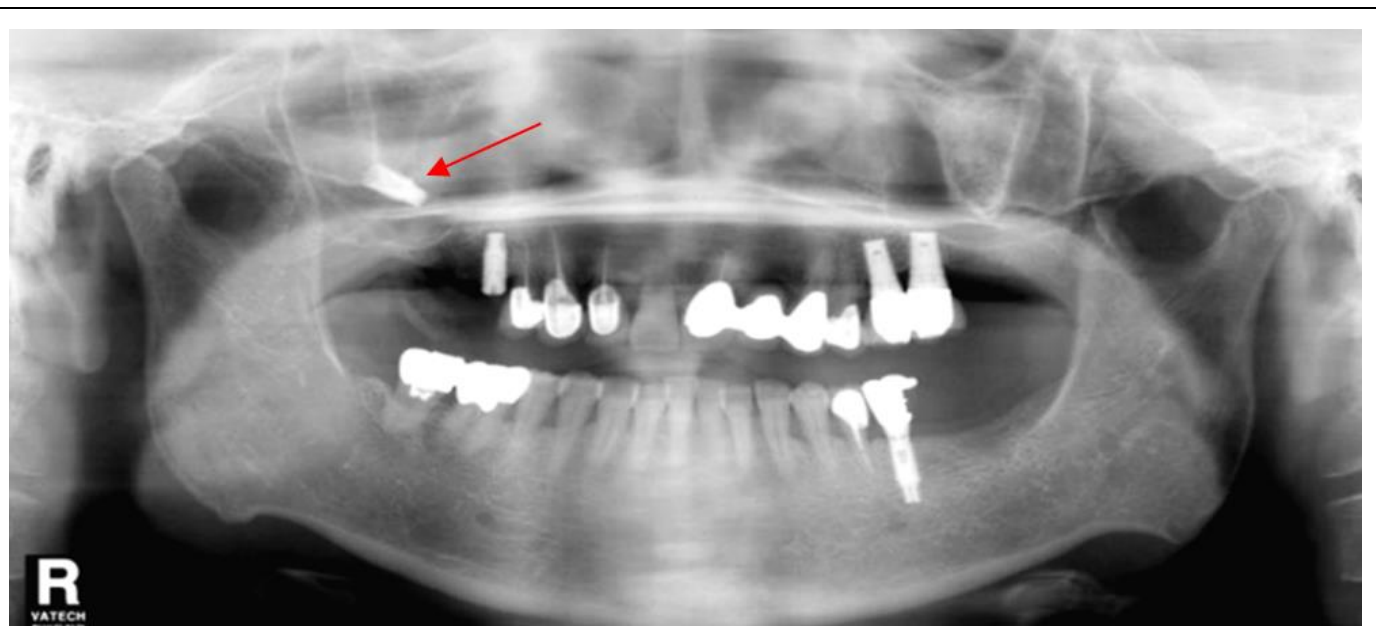

Fig. 19 (Рис. 19)

Fig. 19. Orthopantomogram, performed immediately after implantation in the area of 1.5-1.6.

There is a violation of the integrity of the right maxillary sinus lower wall. In the lower parts of the sinus, an implant is detected placed in the area 1.6 (arrow) [5, 6].

Рис. 19. Ортопантомограмма, выполненная непосреАственно после имплантации в области 1.51.6.

Отмечается нарушение целостности нижней стенки правого верхнечелюстного синуса. В нижних отделах синуса выявляется имплантат, устанавливаемый в область 1.6 (указан стрелкой) [5, 6].

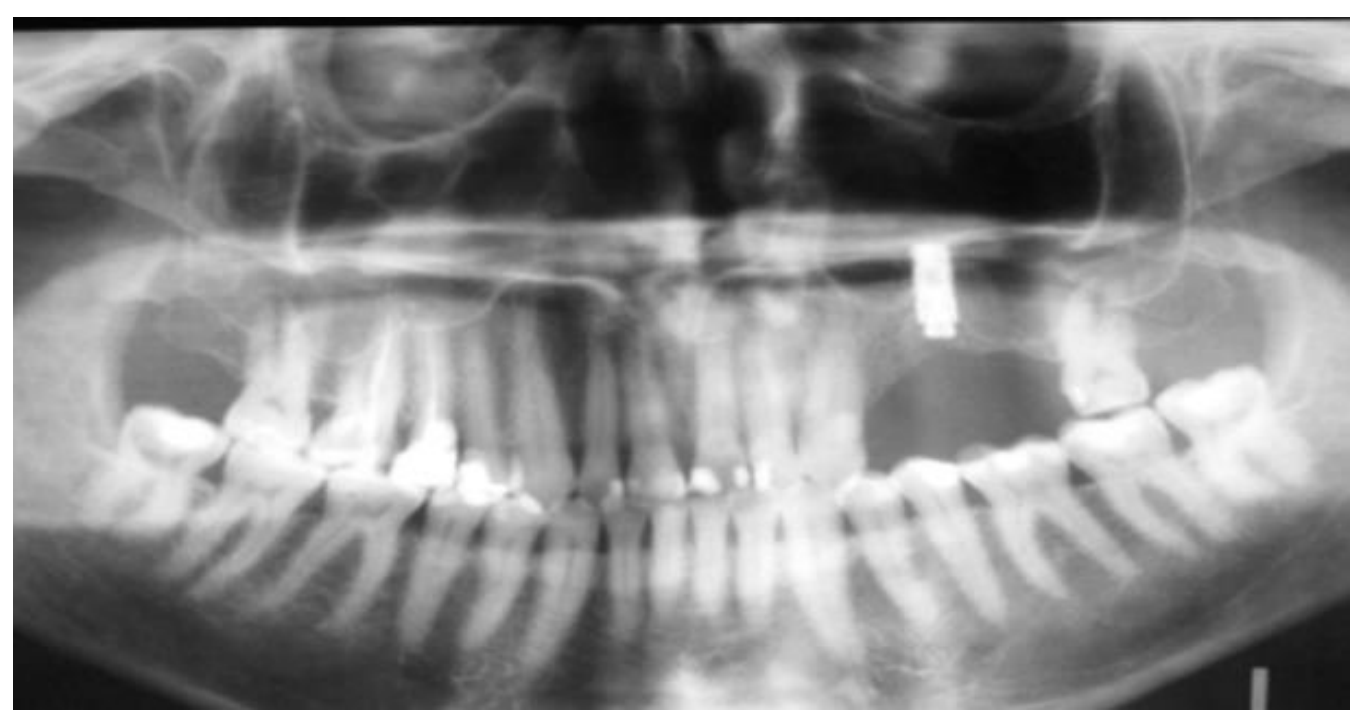

Fig. 20 (Рис. 20)

Fig. 20. Orthopantomogram performed immediately after implantation in the area of tooth 2.5 with a one-stage closed sinus-lifting.

Radiological signs of damage to the lower wall of the left maxillary sinus are revealed. It is difficult to determine the correctness of the implant position in relation to the injected CPM based on the results of this study. This condition is an indication for additional CT [5, 6].

Рис. 20. Ортопантомограмма, выполненная непосреАственно после имплантации в области зуба 2.5 с оАномоментным закрытым синус-Аифтингом.

Выявцяются рентгенологические признаки повреждения нижней стенки цевого верхнечелюстного синуса. Определить правильность стояния имплантата по отношению к введенному КПМ по результатам данного исследования затруднительно. Такое состояния является показанием к дополнительному проведению КТ [5, 6]. 


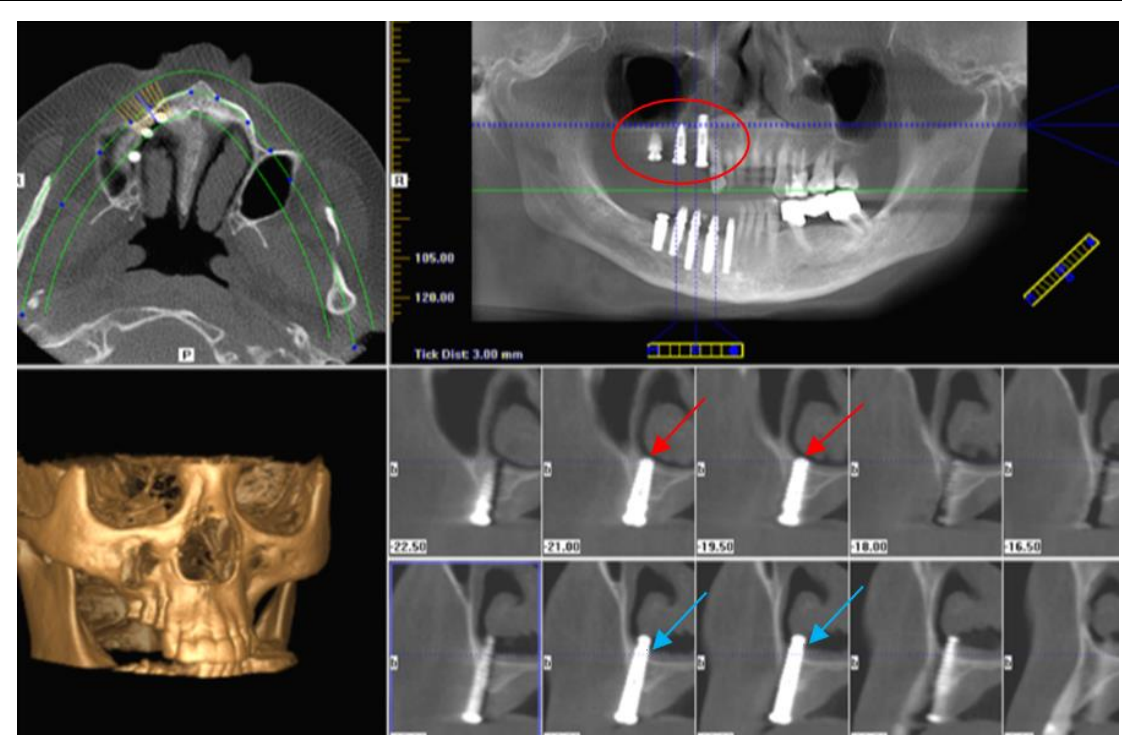

Fig. 21 (Рис. 21)

Fig. 21. СВСТ. Condition after dental implantation surgery in areas 1.4-1.6 and 4.3-4.7.

Damage to the lower wall of the nasal cavity by implants is determined. The 1.5 implant is located apically in the submucosal layer of the nasal cavity (red arrow), the 1.4 implant completely perforates the wall and is positioned 3 $\mathrm{mm}$ in the nasal cavity (blue arrow). The revealed changes were not diagnosed by preliminary X-ray examination and are poorly visualized on panoramic reconstructions (highlighted by an oval) [5, 6].

Рис. 21. КАКТ. Состояние после операции Аентальной имплантации в областях 1.4-1.6 и 4.3-4.7. Определяется повреждение нижней стенки полости носа имплантатами. Имплантат 1.5 апикальной частью располагается в подслизистом слое носовой полости (красная стрелка), имплантат 1.4 полностью перфорирует стенку и располагается на 3 мм в полости носа (голубая стрелка). Выявленные изменения не диагностировались при предварительном рентгенологическом исследовании и плохо визуализируются на панорамных реконструкциях (выдемено овалом) $[5,6]$.

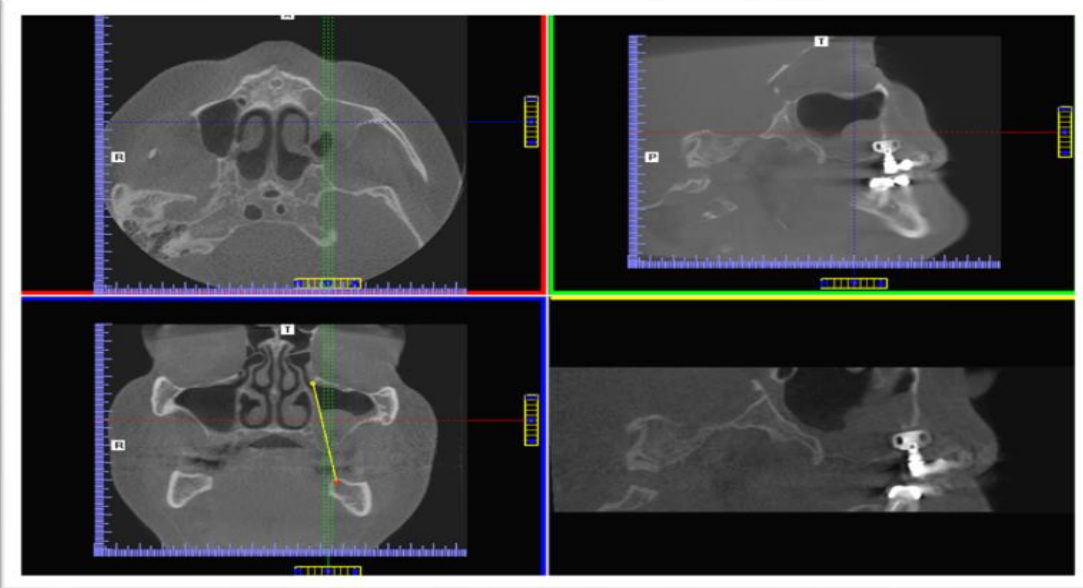

Fig. 22 (Рис. 22)

Fig. 22. СВСТ. Condition after dental implantation surgery on the upper jaw ( 1.5 years after implantation) followed by orthopedic treatment.

There is damage to the anterior and lower walls of the left maxillary sinus, radiological signs of chronic hypertrophic maxillary sinusitis $[5,6]$.

Рис. 22. КАКТ. Состояние после операции Аентальной имп^антации на верхней челюсти (1,5 гоАа после имплантации) с послеАующим ортопеАическим лечением.

Отмечаются повреждение передней и нижней стенок мевого верхнечелюстного синуса, рентгенологические признаки хронического гипертрофического верхнечелюстного синусита $[5,6]$. 


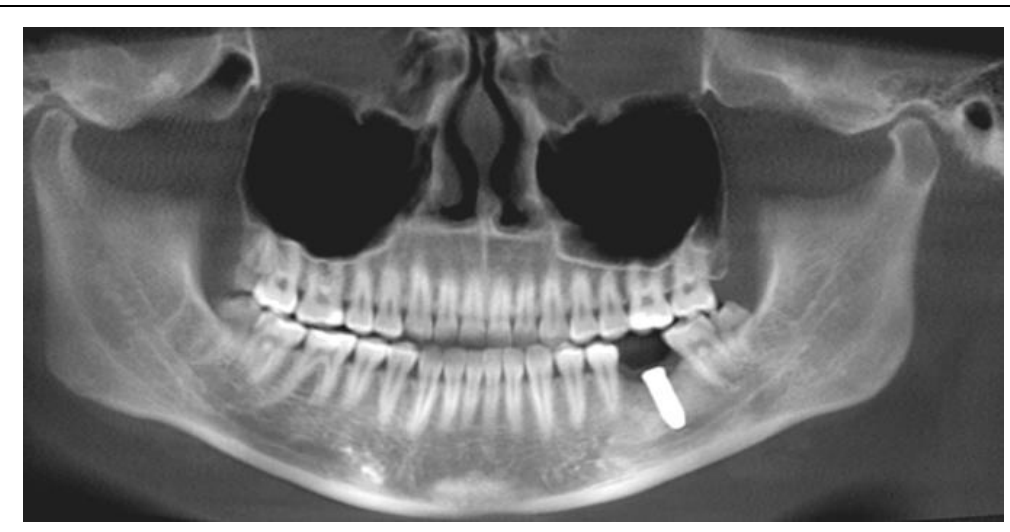

Fig. 23 a (Рис. 23 a)

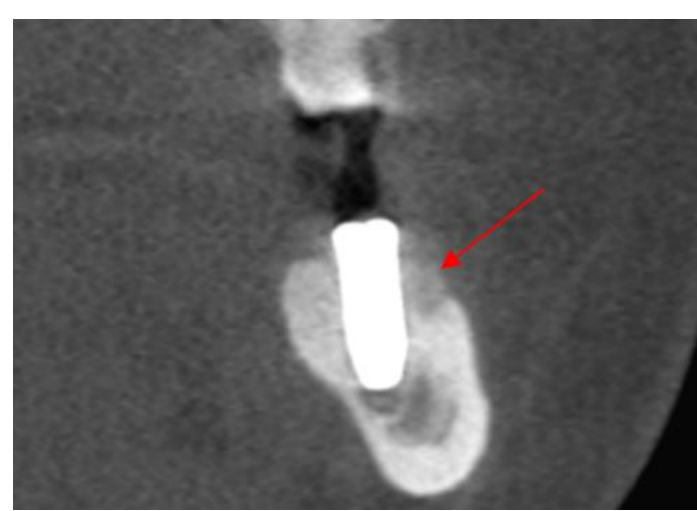

Fig. 23 b (Рис. 23 б)

\section{Fig. 23. $C B C T$, panoramic (a) and multiplanar (b) reconstruction.}

Condition after dental implantation in the area of tooth 3.6 ( 3 weeks after surgery). There are radiological signs of class IV peri-implantitis with pronounced destruction of the vestibular cortical plate, up to $7.5 \mathrm{~mm}$ of vertical resorption (indicated by the arrow) [5, 6].

\section{Рис. 23. КАКТ, панорамная (а) и мультипланарная (б) реконструкции.}

Состояние после дентальной имплантации в области зуба 3.6 (3 недели после операции). Выявляются рентгенологические признаки периимплантита IV класса с выраженной деструкцией вестибулярной кортикальной пластинки, до 7,5 мм вертикальной резорбции (указано стрелкой) [5, 6].

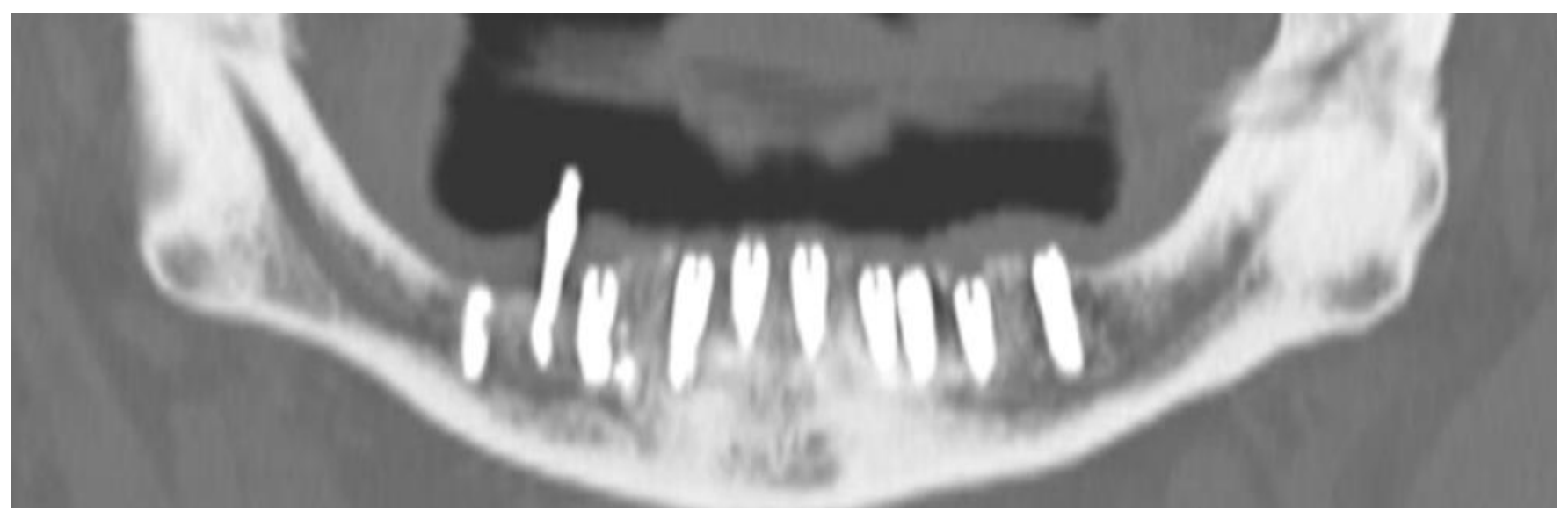

Fig. 24 (Рис. 24)

\section{Fig. 24. MSCT, panoramic reconstruction.}

Condition after simultaneous installation of 10 implants in the lower jaw. Multiple injuries of the mandibular canal and nerve, perforation of the vestibular and lingual cortical plates of the lower jaw alveolar part are determined $[5,6]$.

\section{Рис. 24. МСКТ, панорамная реконструкция.}

Состояние после одномоментной установки 10 имплантатов на нижней челюсти. Определяются множественные повреждения нижнечелюстного канала и нерва, перфорации вестибулярной и язычной кортикальных пластинок альвеолярной части нижней челюсти $[5,6]$. 


\begin{tabular}{|c|c|}
\hline \multicolumn{2}{|c|}{ Radiographic modalities for various treatment stages [5]. } \\
\hline Time limits for X-ray control & The purpose of the study \\
\hline On the day of the DI & Assessment of the implants correct placement \\
\hline $1-1,5$ months after DI & \multirow{2}{*}{$\begin{array}{l}\text { Assessment of the bone structure state at the "implant - bone" border, deter- } \\
\text { mination of the osseointegration degree, detection of bone resorption in the } \\
\text { cervical parts of the implants }\end{array}$} \\
\hline \multirow{2}{*}{$\begin{array}{l}\text { Right before the orthopedic treatment } \\
\text { phase } \\
\text { (3-6 months after DI) }\end{array}$} & \\
\hline & $\begin{array}{c}\text { Control of the height of the alveolar ridge in the peri-implant area before } \\
\text { loading the implant }\end{array}$ \\
\hline $\begin{array}{l}\qquad 1-1,5 \text { months after } \\
\text { the installation of orthopedic elements }\end{array}$ & Assessment of the bone structure state at the "implant - bone" border \\
\hline $\begin{array}{l}1-1,5 \text { years after } \\
\text { the orthopedic treatment }\end{array}$ & $\begin{array}{l}\text { Determination of the rate of bone resorption in the cervical regions of im- } \\
\text { plants in comparison with the control study }\end{array}$ \\
\hline
\end{tabular}

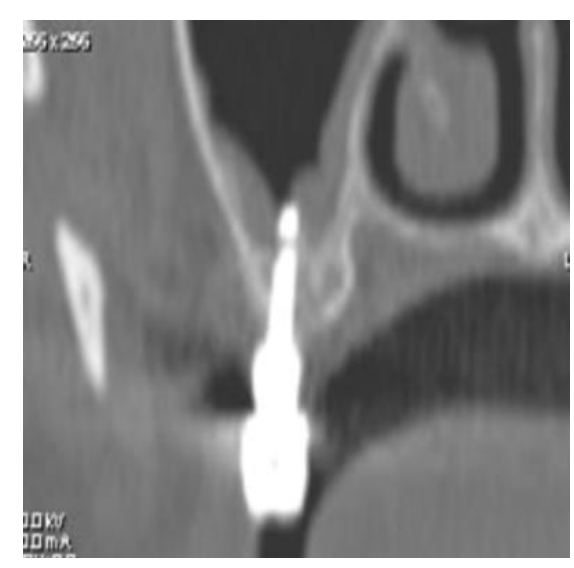

Fig. 25 a (Рис. 25 a)

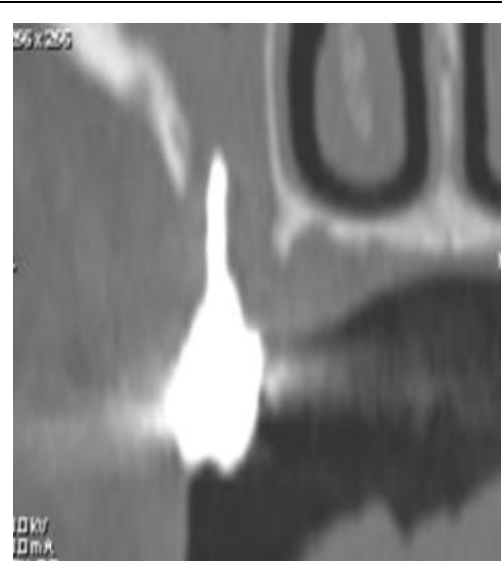

Fig. 25 b (Рис. 25 б)

Fig. 25. MSCT, coronary reconstruction. Condition after dental implantation in the upper jaw and orthopedic treatment.

a - 10 months after implantation and 2 weeks after the installation of suprastructures (perforation of the lower wall of the right maxillary sinus, bone-destructive changes around the body of the implant, radiological signs of right-sided maxillary sinusitis are noted),

b - 2 months later (1 year after implantation and 2.5 months after the orthopedic stage of treatment), complete destruction of the alveolar process in the area of the installed implant, lysis of the lower wall of the maxillary sinus, pronounced manifestations of right-sided maxillary sinusitis are revealed $[5,6]$.

Рис. 25. МСКТ, коронарная реконструкция. Состояние после Аентальной имп^антации на верхней челюсти и ортопеАического лечения.

а - через 10 месяцев после имплантации и 2 недель после установки супраструктур (отмечается перфорация нижней стенки правого верхнечелюстного синуса, костно-деструктивные изменения вокруг тела имплантата, рентгенологические признаки правостороннего верхнечелюстного синусита),

b - через 2 месяца (1 год после имплантации и 2,5 месяца после ортопедического этапа мечения) выявляются полная деструкция альвеолярног отростка в области установленного имплантата, мизис нижней стенки верхнечелюстного синуса, выраженные явцения правостороннего верхнечелюстного синусита [5, 6]. 
implant placement allows better confirmation and accurate implant placement. Imaging after 3 to 5 years and beyond can be used to assess the boneimplant interface and marginal peri-implant bone height. Conventional panoramic radiographs for postoperative assessment of implants are recommended.

Imaging modalities used in postoperative evaluation of the dental implant patient include panoramic radiography, direct axial $\mathrm{CT}$, and reformatted panoramic, cross-sectional, and 3D imaging. Panoramic radiography is undoubtedly the most widely used imaging modality in postoperative evaluation of the dental implant patient; panoramic radiographs are used routinely to assess bone healing around the fixture [5, 6, 19-21] (Fig. 18-20).

CBCT for postoperative care is only recommended if the patient is symptomatic [5, 6, 1921]. This can include evaluation of post-implant complications, such as neurosensory impairment, osteomyelitis, implant mobility, acute rhinosinusitis altered, sensation, and/or pain, and discomfort (Fig. 21-23).

\section{Imaging of DI complications.}

Axial CT and reformatted panoramic, crosssectional and $3 \mathrm{D}$ images can be of great value when one is concerned about possible complications associated with placement of an intraosseous fixture. These include failure to under-go adequate osseous integration, implant loss, incorrect placement of the implant, and violation of adjacent structures [5, 6, 14, 16, 22]. Although the fixture is composed of a metal, usually titanium or

\section{Cписок интературы:}

1. Friedman M. Dental implants. 2019. Available at: https://www.webmd.com/oral-

implants\# 1

2. Oshida Y., Tuna E.B., Aktören O., Gençay K. Dental implant systems. Int. J. Mol. Sci. 2010; 11: 1580-1678.

3. American college of orothdontists. What are the different types of dental implants? 2019. Available at: https://www.dallasdentistryanddentalimplants.com/differenttypes-of-implants/

4. Pure Dentistry. History of dental implant. 2016. Available at: https://dentagama.com/news/history-of-dental-implants

5. Серова Н.С. Аучевая диагностика в стоматологической имплантологии. Диссертаиия на соискание ученой степени доктора медиинских наук. ГОУВПО "Московская медииинская академия". Москва, 2010.

6. Ушаков А.И., Серова Н.С., Даян А.В., Онищенко В.Г., Солодова Н.С., Ибрагим Э.Р. Планирование дентальной имплантаиии при дефииите костной ткани и профилактика операиионных рисков. Часть 1. Аучевая диагностика. Стоматология. 2012; 91 (1): 48-53.

7. Nagarajan A., Perumalsamy R., Thyagarajan R., Namasivayam A. Diagnostic imaging for dental implant therapy. $J$ Clin Imaging Sci. 2014; 4 (Suppl 2): 4. Published 2014 Oct 27. doi:10.4103/2156-

7514.143440 a titanium alloy, there are no major problems in performing CT on dental implants. Axial CT sections are useful in evaluating osseointegration by demonstrating the presence or absence of boneto-metal contact as well as complications associated with implant failure. Cross-sectional reformatted images are useful in assessing osseointegration, while 3D and reformatted panoramic and cross-sectional images are useful in assessing proper placement of a fixture (Fig. 24-25).

The time limits used in different phases of treatment planning at various time intervals and the purpose of the study are given in Table 2 [5].

\section{Conclusion.}

In dental implantation it is very important to have a proper diagnosis before taking a step on doing any implant placement, as the success rate of these procedures depends on the quality of investigation methods. Nowadays conventional radiography is of little importance in implant imaging. Regardless, panoramic radiography remains the technique of choice due to its cost effect. With the advent of $\mathrm{CT}$, quantitative and qualitative analyses of bone can be conducted for implant placement, it rapidly covers an extended anatomic area with reduced patient motion. With the advent of software used in CT, a 3D model can be obtained and the construction of a surgical template is possible. Imaging in dental implantation is required during all the stages of implant placement, as in preoperative planning, intraoperative control and postoperative follow-up.

https://api.ncbi.nlm.nih.gov/lit/ctxp/v1/pmc/?format=medline \&id $=4220422 \&$ download $=$ true
8. Gupta S. et al. Orat
Diagnostic. 2014; 22 (3): A Review https://www.ncbi.nlm.nih.gov/pmc/articles/PMC4681716/

9. Tzerbos F, Bountaniotis F, Theologie-Lygidakis N, Fakitsas D, Fakitsas I. Complications of Zygomatic Implants: Our Clinical Experience with 4 Cases. Acta Stomatol Croat. 2016; 50 (3): 251-257. doi:10.15644/asc50/3/8

10. Balshi T. et al. Immediate loading of dental implants in the edentulous maxilla: Case study of a unique protocol. 2003; 23.

11. Philip Worthington, Jeffrey Rubenstein, David C. Hatcher. The Role of cone-beam computed tomography in the planning and placement of implants. 2010. Available at: <https://jada.ada.org/article/S0002- 8177(14)63741-7/pdf> [Accessed 1 June 2020].

12. Михайлов С. С., Чукбар А. В., Цыбулькин А. Г. Анатомия человека: учебник: в $2 \mathrm{~m}$., под ред. А. А. Колесникова. 5-е изд., перераб. и доп. 2011; 2: 624.

13. Omaid K. Ahmad, Andrew R. Chapokas, Prosthodontics. Diagnostic imaging in the treatment planning, surgical, and prosthodontic aspects of implant dentistry. 2016. [online]. Available

at:<https://www.prosthodontics.org/assets/1/7/Diagnostic_I 


\section{RUSSIAN ELECTRONIC JOURNAL OF RADIOLOGY}

maging_in_the_Treatment_Planning,_Surgical, and_Prosthodontic_Aspects_of_Implant_Dentistry.pdf>

$[A c-$ cessed 1 May 2020].

14. Karjodkar FR. 2nd ed. New Delhi (IND). Implant Radiology. Text book of dental and maxillofacial radiology. 2011; 881-928 https://www.ncbi.nlm.nih.gov/pmc/articles/PMC4681716/ 15. Jayadevappa B.S., Kodhandarama G.S., Santosh S.V., Rashid W.T. Imaging of dental implants. J Oral Health Res. 2010; 1: 50-61.

16. Sanjay M. Mallya. Pharoah's Oral Radiology. Principles and interpretation 8th edition. Clin Oral Implants Res. 2010; 21 : 618-624.

17. Ушаков А.И., Серова Н.С., Ушаков А.А., Юрьев Е.М., Перова Н.Г. Аучевая диагностика при дентальной ииплантаиии в условиях дефииита костной ткани. Российский электронный журнал лучевой диагностики. 2014; 4 (2): 8697.

18. Sang-Yong Yoon. Two bone graft cases using xenograft materials in complicated patients with severe alveolar bone resorption. 2019. Hiossen implant Canada. Available at:

\section{References:}

1. Friedman M. Dental implants. 2019. Available at: https://www.webmd.com/oral- health/guide/dentalimplants\# 1

2. Oshida Y., Tuna E.B., Aktören O., Gençay K. Dental implant systems. Int. J. Mol. Sci. 2010; 11: 1580-1678.

3. American college of prothdontists. What are the different types of dental implants? 2019. Available at: https://www.dallasdentistryanddentalimplants.com/differenttypes-of-implants/

4. Pure Dentistry. History of dental implant. 2016. Available at: https://dentagama.com/news/history-of-dental-implants

5. Serova N.S. Radiology in dental implantology. Doct. Diss. Moscow Medical Academy. Moscow, 2010 (in Russian).

6. Ushakov A.I., Serova N.S., Dayan A.V., Onishchenko V.G., Solodova N.S., Ibragim E.R. Planning of dental implantation in case of bone tissue deficiency and prevention of operational risks. Part 1. Radiation diagnostics. Dentistry. 2012; 91 (1): 4853 (in Russian).

7. Nagarajan A., Perumalsamy R., Thyagarajan R., Namasivayam A. Diagnostic imaging for dental implant therapy. $J$ Clin Imaging Sci. 2014; 4 (Suppl 2): 4. Published 2014 Oct 27. doi:10.4103/2156-

7514.143440

https://api.ncbi.nlm.nih.gov/lit/ctxp/v1/pmc/?format=medline \&id $=4220422 \&$ download $=$ true

8. Gupta S. et al. Oral Implant Imaging: A Review Diagnostic. 2014; $22 \quad$ (3): $23-26$. https://www.ncbi.nlm.nih.gov/pmc/articles/PMC4681716/ 9. Tzerbos $F$, Bountaniotis $F$, Theologie-Lygidakis $N$, Fakitsas $D$, Fakitsas I. Complications of Zygomatic Implants: Our Clinical Experience with 4 Cases. Acta Stomatol Croat. 2016; 50 (3): 251-257. doi:10.15644/asc50/3/8

10. Balshi T. et al. Immediate loading of dental implants in the edentulous maxilla: Case study of a unique protocol. 2003; 23.

11. Philip Worthington, Jeffrey Rubenstein, David C. Hatcher. The Role of cone-beam computed tomography in the planning and placement of implants. 2010. Available at: <https://jada.ada.org/article/S0002- 8177(14)63741-7/pdf> http://www.hiossenimplantcanada.ca/two-bone-graft-casesusing-xenograft-materials-in-complicated- patients-with-severealveolar-bone-resorption/

19. Scarfe W.C., Farman A.G., Sukovik P. Clinical applications of cone-beam computed tomography in dental practice. $J$ Can Dent $\begin{array}{llll}\text { Assoc. } & \text { 2006; } & 72 & \text { (1): }\end{array}$ http://article.sapub.org/ 10.5923.j.ijsr.20150401.01.html 20. Nagarajan Aishwary, Perumalsamy Rajapriya, Ramakrishnan Theyagarajan, Namasivayam, Ambalavanan. Diagnostic imaging for dental implant therapy. Journal of clinical imaging science. 2014. 4. 4. 10.4103/2156-7514.143440.

21. Angelopoulos Christos, Tara Aghaloo. Imaging technology in implant diagnosis. Dental clinics of North America vol. 2011; 55 (1): 141-58. doi:10.1016/j.cden.2010.08.001 https://api.ncbi.nlm.nih.gov/lit/ctxp/v1/pmc/?format=ris\&id=5 348923\&download=true

22. Buhara Oguz, Uyanik L., Ayali Aysa, Ramoglu Melek. Active implant periapical lesions leading to implant failure: two case reports. The Journal of oral implantology. 2012; 40. 10.1563/AAID-JOI-D-11-00127.1.

[Accessed 1 June 2020].

12. Mikhailov S. S., Chukbar A. V., Tsybulkin A. G. Human anatomy: textbook: in 2 volumes, ed. L. L. Kolesnikova. 5th ed., Rev. and add. 2011; 2: 624 (in Russian).

13. Omaid K. Ahmad, Andrew R. Chapokas, Prosthodontics. Diagnostic imaging in the treatment planning, surgical, and prosthodontic aspects of implant dentistry. 2016. Available at:<https://www.prosthodontics.org/assets/ 1/7/Diagnostic_I maging_in_the_Treatment_Planning,_Surgical,_

and_Prosthodontic_Aspects_of_Implant_Dentistry.pdf> cessed 1 May 2020].

14. Karjodkar FR. 2nd ed. New Delhi (IND). Implant Radiology. Text book of dental and maxillofacial radiology. 2011; 881-928 https://www.ncbi.nlm.nih.gov/pmc/articles/PMC4681716/ 15. Jayadevappa B.S., Kodhandarama G.S., Santosh S.V., Rashid W.T. Imaging of dental implants. J Oral Health Res. 2010; 1: 50-61.

16. Sanjay M. Mallya. Pharoah's Oral Radiology. Principles and interpretation 8th edition. Clin Oral Implants Res. 2010; 21 : 618-624.

17. Ushakov A.I., Serova N.S., Ushakov A.A., Yuriev E.M., Perova N.G. Radiology for dental implantation in conditions of bone tissue deficiency. REJR. 2014; 4 (2): 86-97 (in Russian). 18. Sang-Yong Yoon. Two bone graft cases using xenograft materials in complicated patients with severe alveolar bone resorption. 2019. Hiossen implant Canada. Available at: http://www.hiossenimplantcanada.ca/two-bone-graft-casesusing-xenograft-materials-in-complicated- patients-with-severealveolar-bone-resorption/

19. Scarfe W.C., Farman A.G., Sukovik P. Clinical applications of cone-beam computed tomography in dental practice. $J$ Can Dent $\begin{array}{llll}\text { Assoc. } & \text { 2006; } & 72 & \text { (1): }\end{array}$ http://article.sapub.org/ 10.5923.j.ijsr.20150401.01.html 20. Nagarajan Aishwary, Perumalsamy Rajapriya, Ramakrishnan Theyagarajan, Namasivayam, Ambalavanan. Diagnostic imaging for dental implant therapy. Journal of clinical imaging science. 2014. 4. 4. 10.4103/2156-7514.143440. 
21. Angelopoulos Christos, Tara Aghaloo. Imaging technology in implant diagnosis. Dental clinics of North America vol. 2011; 55 (1): $\quad$ 141-58. doi:10.1016/j.cden.2010.08.001 https://api.ncbi.nlm.nih.gov/lit/ctxp/v1/pmc/ ?format $=$ ris\&id $=5$ 348923\&download=true
22. Buhara Oguz, Uyanik L., Ayali Aysa, Ramoglu Melek. Active implant periapical lesions leading to implant failure: two case reports. The Journal of oral implantology. 2012; 40. 10.1563/AAID-JOI-D-11-00127.1. 